\title{
The Reciprocal Interactions between Polyphenols and Gut Microbiota and Effects on Bioaccessibility
}

\author{
Tugba Ozdal ${ }^{1}$, David A. Sela ${ }^{2,+}$, Jianbo Xiao ${ }^{3,+}$, Dilek Boyacioglu ${ }^{4,+}$, Fang Chen ${ }^{5,+}$ and \\ Esra Capanoglu $4, *$ \\ 1 Department of Food Engineering, Faculty of Engineering and Architecture, Okan Univesity, Tuzla, \\ Istanbul TR-34959, Turkey; tugba.ozdal@okan.edu.tr \\ 2 Department of Food Science, University of Massachusetts Amherst, Amherst, MA 01003, USA; \\ davidsela@umass.edu \\ 3 Institute of Chinese Medical Sciences, State Key Laboratory of Quality Research in Chinese Medicine, \\ University of Macau, Taipa, Macau, China; jianboxiao@umac.mo \\ 4 Department of Food Engineering, Faculty of Chemical and Metallurgical Engineering, \\ Istanbul Technical University, Maslak, Istanbul TR-34469, Turkey; boyaci@itu.edu.tr \\ 5 College of Food Science and Nutritional Engineering, National Engineering Research Centre for Fruits and \\ Vegetables Processing, China Agricultural University, Beijing 100083, China; chenfangch@sina.com \\ * Correspondence: capanog1@itu.edu.tr; Tel.: +90-212-285-7340; Fax: +90-212-285-7333 \\ + These authors contributed equally to this work.
}

Received: 8 October 2015; Accepted: 11 January 2016; Published: 6 February 2016

\begin{abstract}
As of late, polyphenols have increasingly interested the scientific community due to their proposed health benefits. Much of this attention has focused on their bioavailability. Polyphenol-gut microbiota interactions should be considered to understand their biological functions. The dichotomy between the biotransformation of polyphenols into their metabolites by gut microbiota and the modulation of gut microbiota composition by polyphenols contributes to positive health outcomes. Although there are many studies on the in vivo bioavailability of polyphenols, the mutual relationship between polyphenols and gut microbiota is not fully understood. This review focuses on the biotransformation of polyphenols by gut microbiota, modulation of gut microbiota by polyphenols, and the effects of these two-way mutual interactions on polyphenol bioavailability, and ultimately, human health.
\end{abstract}

Keywords: polyphenols; phenolics; flavonoids; gut microbiota; microbial metabolism; bioavailability; health; interactions

\section{Introduction}

Polyphenols are secondary metabolites found abundantly in a wide variety of foods, such as fruits, vegetables, herbs, seeds and cereals, and in beverages, such as coffee, tea, cocoa and wine [1]. They are currently a topic of great scientific attention due to the interest in their potential health benefits, which include anti-cancer, anti-oxidant, anti-microbial, anti-inflammatory properties. Polyphenols are also implicated in preventing chronic diseases such as cardiovascular diseases, diabetes, obesity, and neurodegenerative diseases, among others [2-5].

Possible beneficial effects of polyphenols are determined by their bioavailability, among which considerable differences have been observed [6]. Bioavailability is affected by many physicochemical factors such as the type of bioactive compounds, their polarity, molecular mass, plant matrix, their solid state (crystalline vs. amorphous), and digestibility by gastrointestinal enzymes, and absorption into the enterocytes. Bioaccessibility, the determinant of release and solubility of bioactive compounds during digestion for further uptake and absorption, is another important factor for bioavailability [7]. In order 
to understand bioavailability of phenolic compounds and their potential benefits, determination of bioaccessibility during digestion is important.

Most polyphenols pass through the small intestine without being absorbed, thus encountering the gut microbiota which colonizes the colon [8]. This has led to the development of a two-way mutual reaction between polyphenolic compounds and gut microbiota. First, polyphenols are biotransformed into their metabolites by gut microbiota that results in the increased bioavailability of polyphenols. Second, polyphenols modulate the composition of the gut microbial community mostly through the inhibition of pathogenic bacteria and the stimulation of beneficial bacteria. In the latter, they may act as a prebiotic metabolite and enrich the beneficial bacteria [9]. Therefore, the interactions of dietary polyphenols and gut microbiota may result in impact on human host health.

Due to the recent attention paid to these interactions, a number of important reviews have been published focusing on both ends of the relationship - the effect of phenolics on the gut microbiota composition, and the effect of gut microbiota on the biotransformation of phenolic compounds, their bioavailability, or human health [10-19]. The aim of this review is to provide an overview of the two-way reciprocal relationship of all the sub-classes of phenolic compounds and gut microbiota and the relevance of these interactions to bioavailability and human health.

\section{Polyphenols, Gut Microbiota and Health}

Polyphenols are a large group of heterogeneous compounds characterized by hydroxylated phenyl moieties, and are found mostly in plants, including fruits, vegetables, and cereals, as well as derived beverages such as tea, coffee and wine [20]. Polyphenols have become an intense focus of research due to their potential benefits to health, particularly in relation to the prevention of cancer [21,22] and cardiovascular diseases [23,24]. Suggested beneficial effects are anticarcinogenic [25,26], antiatherogenic [27,28], antiulcer [29], antithrombotic [30,31], anti-inflammatory [32,33], antiallergenic [34,35], anticoagulant [36], immune modulating [37], antimicrobial [38,39], vasodilatory [40], and analgesic activities [41]. To achieve these health benefits, polyphenols require in situ processing by the gut microbiota to be transformed into a potentially more bioactive, low-molecular-weight metabolite [42]. Faria et al. (2014) reviewed that total polyphenol absorption in the small intestine is relatively low $(5 \%-10 \%)$ in comparison to other macro- or micronutrients. The remaining $90 \%-95 \%$ of polyphenols transit to the large intestinal lumen and accumulate in the millimolar range. From the lumen, together with conjugates excreted from bile, they are exposed to the enzymatic activities of the gut microbiota [43].

The microbiota that colonize the distal regions of the colon represent the highest concentration of microorganisms found in human body, as well as the most diverse [44]. It is known that the human gut has an ecosystem of around $10^{13}-10^{14}$ bacterial cells, an estimate 10 times that of human somatic cells [45]. In addition, the aggregate microbial genome (i.e., microbiome) is predicted to contain more than three million genes, or 150 times more than human genes [46]. In short, the gut microbiota is essential for the maintenance of intestinal homeostasis and human health [47].

The reciprocal relationship between polyphenols and gut microbiota may contribute to host health benefits. The need to clarify the molecular mechanisms underlying the observed prebiotic enrichment of beneficial bacteria and antimicrobial activities against gut pathogenic bacteria is apparent [42,48-52]. Commensals residing in the gut may improve health by protecting against gastrointestinal disorders and pathogens, processing nutrients, reducing serum cholesterol, strengthening intestinal epithelial tight cell junctions, increasing mucus secretion and modulating intestinal immune response through cytokine stimulus $[53,54]$. Furthermore, the gut microbiota biotransforms polyphenols into metabolites that may have greater biological activity than their precursor structures [42].

\section{Metabolism of Phenolics and Microbial/Colonic Metabolic Pathways}

Phenolics are mostly found bound to sugars and organic acids that can be grouped into flavonoids and non-flavonoids. Figures 1 and 2 exhibit the structure of flavonoid-type phenolics 
and nonflavonoid-types, respectively. Flavonoid-type phenolics have a primary structure existing of two benzene rings, $\mathrm{A}$ and $\mathrm{B}$, connected through a heterogeneous pyrone $\mathrm{C}$ ring. In contrast, nonflavonoid-type phenolics have a more diverse group of compounds from the simplest C6-C1 benzoic acids to more complicated C6-C2-C6 stilbenes, C6-C3-C3-C6 lignans and gallotannins, hydrolyzable tannins and ellagitannins [42].<smiles></smiles>

FLAVONES

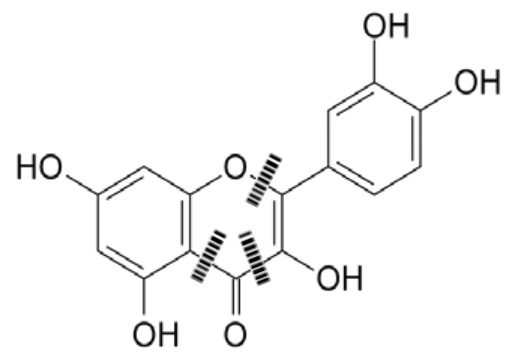

FLAVONOLS (quercetin)

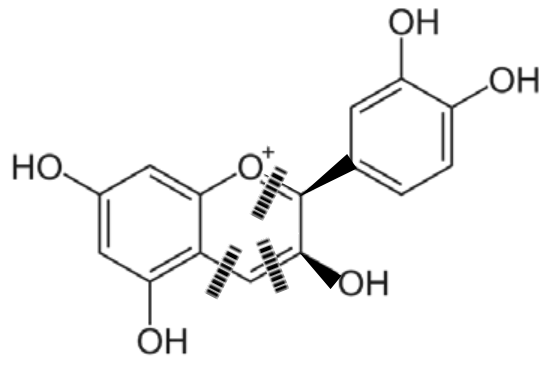

FLAVAN-3-OLS (epicatechin)<smiles>CC(C)=CC(=O)c1c(O)cc(O)cc1O</smiles>

ISOFLAVONES (genistein)<smiles>CC(=O)c1c(O)cc(O)cc1OCC(C)Cc1ccc(O)cc1</smiles>

FLAVANONES (naringenin)

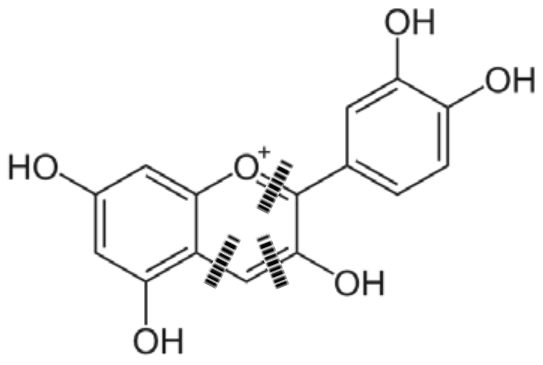

ANTHOCYANINS (cyanidin)

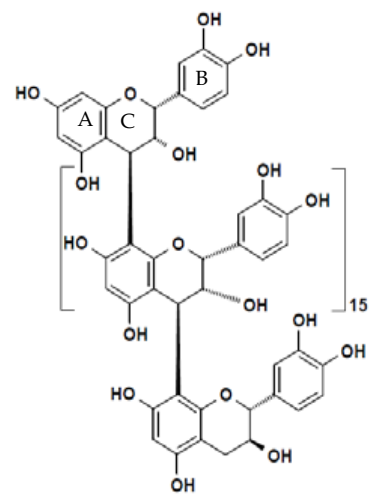

CONDENSED TANNINS (epicatechin16-(4 $\rightarrow$ 8)-catechin)

Figure 1. Microbiota heterocyclic $C$ ring cleavage of flavonoids; $(\mathrm{I} \mid \mathrm{I})$ positions of the potential C-ring cleavages [42]. 


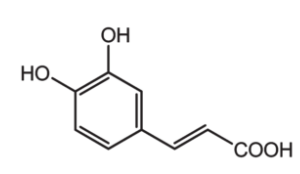

Hydroxycinnamates (caffeic acid)

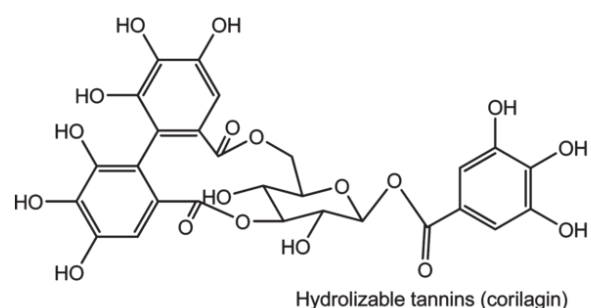

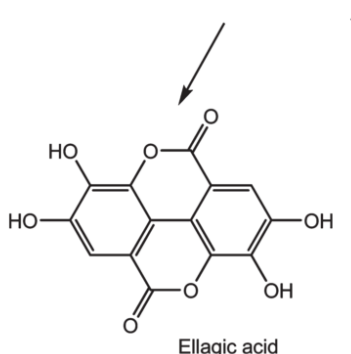

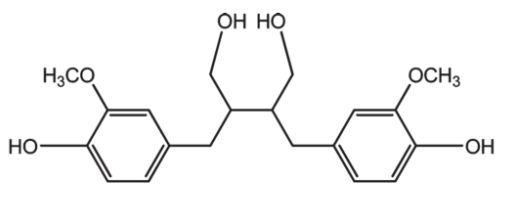

Lignans (secoisolariciresinol)
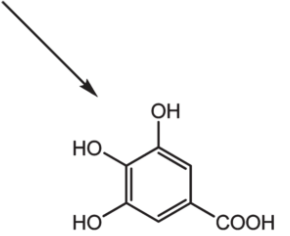

Benzoic acids (gallic acid)<smiles>Oc1ccc(/C=C/c2cc(O)cc(O)c2)cc1</smiles>

Stilbenes (resveratrol)

Figure 2. Nonflavonoid-type phenolics that are metabolized by the gut microbiota [42].

\subsection{Flavonoid-Type Phenolics}

\subsubsection{Flavonols}

Flavonols contain a 3-hydroxyflavone base (3-hydroxy-2-phenylchromen-4-one) and have a planar ring system (Figure 1). They are differentiated by their hydroxy modification at distinct positions of the phenol residue. Foods particularly enriched in flavonols are onions, broccoli, tea, apples, and red wine [55]. Flavonols are extensively hydrolyzed into their metabolite-derivative products by gut microbiota at the $\mathrm{A}$ and $\mathrm{B}$ rings as a result of the $\mathrm{C}$ ring cleavage [56,57]. Accordingly, quercetin provides 2-(3,4-dihydroxyphenyl)acetic acid, 2-(3-hydroxyphenyl)acetic acid, and 3,4-dihydroxybenzoic acid from the B ring, while phloroglucinol, 3-(3,4-dihydroxyphenyl)propionic acid, and 3-(3-hydroxyphenyl)propionic acid are formed from the A ring. Additional phenolic-metabolites such as 3-methoxy-4-hydroxy-benzoic acid (vanillic acid), 2,4,6-trihydroxybenzoic acid, 2-(3,4-dihydroxyphenyl)ethanol, 3,4-dihydroxybenzaldehyde, 3-(3,4-dihydroxyphenyl)benzoic acid methyl ester, and 3-( $m$ or $p$-hydroxyphenyl) propionic acid have also been recognized. The types of phenolic compounds produced are affected by the mechanism of B ring hydroxylation. Myricetin trihydroxylation produces 2-(3,5-dihydroxyphenyl)acetic acid, 2-(3-hydroxyphenyl)acetic acid, and 2-(3,4,5-trihydroxyphenyl)acetic acid. Moreover, kaempferol (which has a 4'-hydroxy-ring B), releases only 2-(4-hydroxyphenyl)acetic acid. In summary, flavonols are biotransformed by $\mathrm{C}$ ring fission, and later by dehydroxylation reactions in the intestine [58].

\subsubsection{Flavones and Flavanones}

Flavones are flavonoids that have a basic structure consisting of a 2-phenyl-benzo- $\gamma$-pyrone skeleton formed by two phenyl rings (A and B) linked with a heterocyclic pyrone ring (C) (Figure 1). Flavanones have a 2,3-dihydro-2-phenylchromen-4-one structure. (Figure 1). The pyran rings of flavanones are nonlinear because they contain saturated C2-C3 bonds. They can form linkages with estrogen receptors. Furthermore, they do not contain double bonds between C2 andC3, contrary to isoflavones (Figure 1). Citrus fruits such as lemon, grapefruit, and orange are the most important dietary sources of flavanones [59]. 
In comparison, flavanones have a higher bioavailability compared to flavonols and flavan-3-ols. This could be explained in part by less degradation by gut microbiota and greater accessibility for absorption in the intestine. Flavanones occur as glycosides, usually rutinosides (6-O- $\alpha$-L-rhamnosyl-D-glucosides) and neohesperidosides (2-O- $\alpha$-L-rhamnosyl-D-glucosides) at the seventh position [60]. The degradation pathways of flavanone glycosides such as naringin are similar to flavonols. The first reaction is a deglycosylation to form naringenin, which then turns into phloroglucinol and 3-(3,4-dihydroxyphenyl)propionic acid by cleavage of the C ring [58].

\subsubsection{Flavone C-Glycosides}

Most dietary flavonoids exist in their O-glycosidic forms. However, C-glycosylated flavonoids, especially flavones, are widespread in a variety of plants [61]. In most cases, flavone O-glycosides are hydrolyzed by digestive enzymes or degraded by gut bacteria to their aglycones in the intestine to be reduced and conjugated to form $O$-glucuronides and $O$-sulfates in the liver $[62,63]$. However, flavone C-monoglucosides exhibit different metabolism pathways compared to flavone $C$-multiglycosides [63] (Figure 3). Flavone C-monoglucosides such as orientin, vitexin, homoorientin, and isovitexin are observed to be poorly absorbed in the gastrointestinal tract of rats and, consequently, were able to reach the colon [64]. Once in the colon, flavone C-monoglucosides are deglycosylated and degraded to smaller metabolites, such as phloroglucinol, hydrocaffeic acid, and phloretic acid, by human gut bacteria, yielding very few metabolites in the urine and blood. Flavone $C$-multiglycosides are absorbed intact in the intestine and are minimally changed in the liver. Afterwards, they are returned to the gut by enterohepatic recirculation [63].

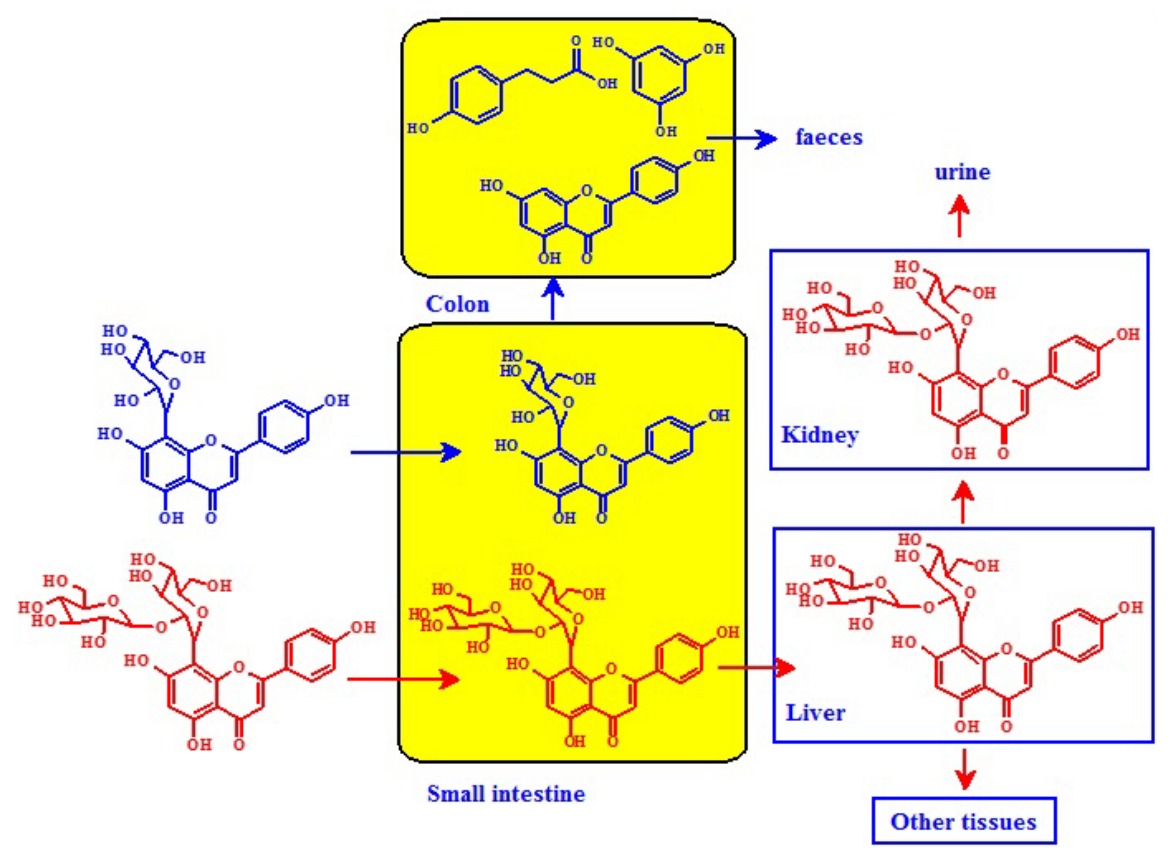

Figure 3. Absorption and metabolism of flavone $C$-monoglycosides (blue arrow) and C-multiglycosides (red arrow) [63].

\subsubsection{Isoflavones}

Isoflavones have a planar basic ring system with the benzenoid B ring attached to C3, differentiating it from the other flavonoids. Isoflavonoids are nonsteroidal and estrogen-like due to their chemical structure. As they are able to bind to estrogen receptors (ER $\alpha$ and ER $\beta$ ), they are classified as natural selective estrogen receptor modulators (SERMs) [65-70]. Isoflavones are in the form of water-soluble glycosides and they cannot be absorbed completely through the enterocyte. 
This is a consequence of their high hydrophilicity and molecular weight. Soy is one of the food products rich in health-promoting isoflavonoids [65]. Soy products contain 12 identified isoflovone compounds: three aglycones (genistein, daidzein, glycitein); three glucosides; three acetyl ester glucosides; and three malonyl ester glucosides. Isoflavones can be biotransformed by $\beta$-glucosidase from gut microbiota into their aglycones for increased bioavailability $[70,71]$. The aglycones can be both absorbed completely or metabolized by gut microbiota [72]. Aglycones are also biotransformed into their metabolites, namely daidzein to $O$-demethylangolensin $(O-D M A)$ and equol, and genistein to $p$-ethylphenol and 4-hydroxyphenyl-2-propionic acid. Equol has higher antioxidant activity than soy isoflavones due to its nonplanar structure which is more flexible to conformational modification. Though, due to the absence of specific constituents of the gut microbiota, only about one-third of the human population can metabolize daidzein into equol. Other observed microbial metabolites of daidzein are 2-dehydro-O-DMA, dihydrodaidzein, tetrahydrodaidzein, 6-hydroxydaidzein, 8-hydroxydaidzein, and 3'-hydroxydaidzein, and 3-(4-hydroxyphenyl)benzopyran-4,7-diol. They are biotransformed by deglucosylation, reduction, $\mathrm{C}$ ring fission, and hydroxylation reactions [65]. Soybean products contain less than $10 \%$ glycitein, but it comprises about half of the isoflavone mass in soy germ. It is demethoxylated into $6,7,4^{\prime}$-trihydroxyisoflavone in vitro by Eubacterium limosum [73]. Metabolites of glycitein have been isolated and characterized as dihydroglycitein, 6-O-methyl-equol, 5'-O-methyl-O-desmethylangolensin, and dihydro-6,7,4'-trihydroxyisoflavone [74,75].

\subsubsection{Flavanols}

Simple flavanols such as (+)-catechin (C), (-)-epicatechin (EC), epigallocatechin, their gallate esters, and polymeric procyanidins from dimers and polymers collectively named condensed tannins are all classified as flavanols. They are the primary contributors to dietary phenolics and are found mostly in fruits, tea, wine and chocolate. Similar to flavanones and flavonols, flavanols such as catechin, epigallocatechin and epicatechin have a B ring attached to $\mathrm{C} 2$, but they do not have a carbonyl group in their $\mathrm{C} 4$ position or double bonds between $\mathrm{C} 2$ and $\mathrm{C} 3$. They are not found in a planar conformation as flavanones are [42].

Flavanols are promptly metabolized to several $O$-sulfated, $O$-glucuronidated, and $O$-methylated forms by phase II enzymes [76-79]. The main phenolic-metabolites of catechin and epicatechin are 5- $\left(3^{\prime}, 4^{\prime}-\right.$ dihydroxyphenyl)- $\gamma$-valerolactone, 3-(3-hydroxyphenyl)propionic acid, and 3-hydroxyhippuric acid, 5 -(3'-hydroxyphenyl)- $\gamma$-valerolactone $[58,80,81]$. Tzounis et al. (2008) found out that when (-)-epicatechin or $(+)$-catechin were incubated with intestinal bacteria, 5-( $3^{\prime}, 4^{\prime}$-dihydroxyphenyl)- $\gamma$-valerolactone, 5-phenyl- $\gamma$-valerolactone, and 3-phenylpropionic acid were formed [48]. For the biotransformation of these metabolites to proceed, initial conversion to (+)-epicatechin from (+)-catechin is essential. The metabolites pyrogallol, 3-(3-hydroxyphenyl)propionic acid, 5-(3,4-dihydroxyphenyl)valeric acid, 5-(3-hydroxyphenyl)valeric acid, 3-(3,4-dihydroxyphenyl)propionic acid, 3-(3-methoxyphenyl) valeric acid, and 2,3-dihydroxyphenoxyl 3-(3', $4^{\prime}$-dihydroxyphenyl)propionic acid are obtained after in vitro incubation of epicatechin with the human intestinal microbial community. Dietary condensed tannins are biotransformed into benzoic, phenylacetic, phenylpropionic, and phenyllactic acid derivatives, with phloroglucinol, 5-(3'-hydroxyphenyl)- $\gamma$-valerolactone, and 1-(3-hydroxyphenyl)-3(2,4,6-trihydroxyphenyl)propan-2-ol being produced [82]. In another study, condensed tannins produced 3-(4-hydroxyphenyl)propionic acid, 3-phenylpropionic acid, 2-(3-hydroxyphenyl)acetic acid, 2-(4-hydroxyphenyl)acetic acid, 5-(3-hydroxyphenyl)valeric acid, and 3-(3-hydroxyphenyl)propionic acid by way of the gut microbiota [80].

The dry weight of green tea consists of $30 \%-42 \%$ catechin. Major catechins are (+)-epigallocatechin gallate (EGCG), (-)-epigallocatechin (EGC), (-)-epicatechin gallate (ECG), and (-)-epicatechin (EC), in which EGCG is the most abundant, and may account for $50 \%-80 \%$ of the total catechins in tea [83]. The metabolism of tea catechins by gut microbiota has been studied extensively, demonstrating that the absorption of catechins in the small intestine is relatively low. As a result, the majority of tea catechins are biotransformed by gut microbiota, followed by absorption in the bloodstream or excretion in the feces. 
Recently, Takagaki and Nanjo (2013) identified several new metabolites of (+)-C or (-)-EC biotransformed by rat intestinal microbiota and they revised the suggested metabolic pathway of these compounds [84]. They have observed four different strains of human intestinal bacteria that have the ability to biotransform (+)-C and (-)-EC.

Wang et al. (2001) reported that Eubacterium sp. strain SDG-2 biotransformed (+)-C to 1-( $3^{\prime}, 4^{\prime}-$ dihydroxyphenyl)-3-(2",4",6"-trihydroxyphenyl)propan-2-ol. However, the bacteria biotransformed (-)-EC into two compounds, 1-(3',4'-dihydroxyphenyl)-3-(2", 4", 6"'-trihydroxyphenyl)propan-2-ol and 1-(3'-hydroxyphenyl)-3-(2", 4",6"'-trihydroxyphenyl)propan-2-ol. Thus, Eubacterium sp. strain SDG-2 has the ability of $p$-dehydroxylation in the B ring of (-)-EC but not in (+)-C [85].

Recently, Kutschera et al. (2011) revealed that both (+)-C and (-)-EC could be biotransformed to 1-(3',4'-dihydroxyphenyl)-3-(2",4",6"-trihydroxyphenyl)propan-2-ol by Eggerthella lenta rK3. However, the conversion of (+)-C progressed five times faster than that of (-)-EC. Flavonifractor plautii aK2 further converted 1-(3',4'-dihydroxyphenyl)-3-(2", $4^{\prime \prime}, 6^{\prime \prime}$-trihydroxyphenyl)propan-2-ol to $\delta$-( $\left(3^{\prime}, 4^{\prime}\right.$-dihydroxyphenyl)- $\gamma$-valerolactone and $\delta$-( $3^{\prime}, 4^{\prime}$-dihydroxyphenyl)- $\gamma$-valeric acid [86].

EGC can be biotransformed by Eubacterium sp. strain SDG-2 into 1-(3',5'-dihydroxyphenyl)-3(2", $4^{\prime \prime}, 6^{\prime \prime}$-trihydroxyphenyl)propan-2-ol [85]. Moreover, it was observed that 5-( $3^{\prime}, 4^{\prime}, 5^{\prime}$-trihydroxyphenyl)$\gamma$-valerolactone can be formed as an additional major metabolite of EGC $[77,78]$.

Furthermore, it was reported that some phenolic acids were produced such as 3,4-DHPPA, 3-HPPA, 4-HPPA), 3,4-DHPAA, 3-HPAA, 3-HBA, 4-HBA and phloroglucinol [87-89]. Meng et al. (2002) identified $\delta$-( $3^{\prime}, 4^{\prime}, 5^{\prime}$-trihydroxyphenyl)- $\gamma$-valerolactone, $\delta$-( $3^{\prime}, 4^{\prime}$-dihydroxyphenyl)- $\gamma$-valerolactone, and $\delta$-(3',5'-dihydroxyphenyl)- $\gamma$-valerolactone in the urine after EGC consumption [90]. Upon consumption of $200 \mathrm{mg}$ of pure ECG, $\delta$ - $\left(3^{\prime}, 4^{\prime}, 5^{\prime}\right.$-trihydroxyphenyl $)-\gamma$-valerolactone, $\delta-\left(3^{\prime}, 4^{\prime}-\right.$ dihydroxyphenyl)- $\gamma$-valerolactone, and $\delta$-( $3^{\prime}, 5^{\prime}$-dihydroxyphenyl)- $\gamma$-valerolactone were identified in the urine [90].

Furthermore, (-)-EGCG is the 3-O-gallate product of (-)-EGC, which is the major catechin derivative found in tea. Van't Slot and Humpf (2009) reported that (+)-GCG and (-)-EGCG were degraded by the intestinal microbiota of pig cecum, and biotransformed into (+)-GC and (-)-EGC, respectively [89]. This degradation is also observed by human and rat intestinal microbiota in in vitro models of the colon [88,91]. In addition, Takagaki and Nanjo (2010) analyzed the metabolism and biotransformation of (-)-EGCG by rat intestinal bacteria and proposed three metabolic pathways. In the first step, (-)-EGCG is hydrolyzed into (-)-EGC and gallic acid. Then, EGC is biotransformed into 1-(3',4',5'-trihydroxyphenyl)-3-(2", 4", $6^{\prime \prime}$-trihydroxyphenyl)propan-2-ol by reductive opening among the first and second positions of EGC. Subsequently, 1-(3',4',5'-trihydroxyphenyl)-3-(2",4",6"'-trihydroxyphenyl)propan-2-ol is biotransformed into 1-(3',5'-dihydroxyphenyl)-3-(2", $4^{\prime \prime}, 6^{\prime \prime}$-trihydroxyphenyl)propan-2-ol by dehydroxylation of 1-(3',4',5'-trihydroxyphenyl)-3-(2", $4^{\prime \prime}, 6^{\prime \prime}$-trihydroxyphenyl)propan-2-ol at the $4^{\prime}$ position. Moreover, as a moor degradation pathway of EGCG metabolism, 5-( $3^{\prime}, 5^{\prime}$-dihydroxyphenyl)- $\gamma$-valeric acid is formed as the main metabolite by ring fission of the phloroglucinol moiety of the metabolite 1-(3',5'-dihydroxyphenyl)-3-(2", 4", 6"'-trihydroxyphenyl)propan-2-ol. This is the major pathway of EGCG metabolism. Simultaneously, just after the ring fission, the $5-\left(3^{\prime}, 5^{\prime}\right.$-dihydroxyphenyl $)-\gamma$-valerolactone metabolite may be formed according to the lactonization of $5-\left(3^{\prime}, 5^{\prime}\right.$-dihydroxyphenyl)- $\gamma$-valeric acid and its small part is biotransformed into 3,5-dihydroxyphenyl-propionic acid. In addition, an insignificant amount of $4^{\prime}$-dehydroxylated metabolite is biotransformed from EGC that is not further metabolized by the gut microbiota [91].

There are also in vivo studies on the metabolism of EGCG explaining the likely metabolic pathway as in in vitro studies. In vivo studies on the biotransformation of EGCG after oral administration to rats revealed that EGCG was relocated into the cecum and large intestine, and then underwent degradation by intestinal bacteria to 5-(3',5'-dihydroxyphenyl)- $\gamma$-valerolactone with EGC as an intermediate product $[92,93]$. An abundant quantity of 5-(3, $5^{\prime}$-dihydroxyphenyl $)-\gamma$-valerolactone is absorbed in the body by going through glucuronidation in the intestinal mucosa or liver, transformed to its glucuronidated metabolites which enter blood circulation. Next they are distributed to various tissues 
and excreted in the urine $[90,92,93]$. In vivo and in vitro biotransformations of flavan-3-ols are given in detail with their degradation products in Table 1.

Table 1. In vitro and in vivo biotransformation of flavan-3-ols by gut microbiota.

\begin{tabular}{|c|c|c|}
\hline Compound & Metabolite & $\begin{array}{l}\text { Model (in Vivo/in Vitro) } \\
\text { and References }\end{array}$ \\
\hline \multirow{16}{*}{$(+)-\mathrm{C}$ or $(-)-\mathrm{EC}$} & 1-(4'-hydroxyphenyl)-3-(2",4",6"-trihydroxyphenyl)propan-2-ol & Rat in vitro [84] \\
\hline & 1-(3'-hydroxyphenyl)-3-(2", $4^{\prime \prime}, 6^{\prime \prime}$ - trihydroxyphenyl)propan-2-ol & Rat in vitro [84] \\
\hline & 1-(3',4'-dihydroxyphenyl)-3-(2", 4",6"-trihydroxyphenyl)propan-2-ol & Rat in vitro [84] \\
\hline & 5-(3'-hydroxyphenyl)pentanoic acid & Rat in vitro [84] \\
\hline & 5-( $3^{\prime}, 4^{\prime}$-dihydroxyphenyl)-4-oxo-valeric acid & Rat in vitro [84] \\
\hline & 5-(3'-hydroxyphenyl)-4-oxo-valeric acid & Rat in vitro [84] \\
\hline & 5-[(3',4'-dihydroxyphenyl)methyl]oxolan-2-one & $\begin{array}{l}\text { Rat in vitro [84]; Human in vitro [87]; } \\
\text { Human in vivo [90] }\end{array}$ \\
\hline & 5-[(3'-hydroxyphenyl)methyl)oxolan-2-one & Rat in vitro [84]; Human in vitro [88] \\
\hline & 5-( $3^{\prime}, 4^{\prime}$-dihydroxyphenyl)-pentanoic acid & Rat in vitro [84]; Human in vitro [87] \\
\hline & 3,4-DHPPA & Rat in vitro [84]; Pig in vitro [89] \\
\hline & 3-HPPA & Rat in vitro [84]; Human in vitro [87] \\
\hline & 4-HPAA & Pig in vitro [89] \\
\hline & 3-HBA & Pig in vitro [89] \\
\hline & 4-HBA & Pig in vitro [89] \\
\hline & Phloroglucinol & Pig in vitro [89] \\
\hline & 5-[(3', $4^{\prime}, 5^{\prime}$-trihydroxyphenyl)methyl]oxolan-2-one & Human in vitro [88] \\
\hline \multirow{8}{*}{$(+)-G C$ or $(-)$ EGC } & 1-(3',5'-dihydroxyphenyl)-3-(2", $4^{\prime \prime}, 6^{\prime \prime}$ - trihydroxyphenyl)propan-2-ol & Human in vitro $[87,88]$ \\
\hline & 5-[(3', $4^{\prime}, 5^{\prime}$-trihydroxyphenyl)methyl]oxolan-2-one & Human in vitro $[87,88]$ \\
\hline & 4-HPAA & Human in vitro [87]; Pig in vitro [89] \\
\hline & Phloroglucinol & Pig in vitro [89] \\
\hline & 3,4-DHPPA & Pig in vitro [89] \\
\hline & 3-HPPA & Pig in vitro [89] \\
\hline & 3-HBA & Pig in vitro [89] \\
\hline & 4-HBA & Pig in vitro [89] \\
\hline \multirow{3}{*}{$(-)$-EGC } & 5-[(3', $4^{\prime}, 5^{\prime}$-trihydroxyphenyl)methyl]oxolan-2-one & Human in vivo [90] \\
\hline & 5-[(3',4'-dihydroxyphenyl)methyl]oxolan-2-one & Human in vivo [90] \\
\hline & 5-[(3',5'-dihydroxyphenyl)methyl)]oxolan-2-one & Human in vivo [90] \\
\hline \multirow{10}{*}{$(-)$-ECG } & EC & Rat in vivo $[92,93]$ \\
\hline & Gallic acid & Rat in vivo $[92,93]$ \\
\hline & Pyrogallol & Rat in vivo $[92,93]$ \\
\hline & 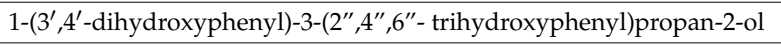 & Rat in vivo $[92,93]$ \\
\hline & 5-[(3',4'-dihydroxyphenyl)methyl]oxolan-2-one & Rat in vivo $[92,93]$ \\
\hline & 5-[(3'-hydroxyphenyl)methyl)]oxolan-2-one & Rat in vivo $[92,93]$ \\
\hline & 5-( $3^{\prime}, 4^{\prime}$-dihydroxyphenyl)pentanoic acid & Rat in vivo $[92,93]$ \\
\hline & 3-HPPA & Rat in vivo $[92,93]$ \\
\hline & (E)-3-(3-hydroxyphenyl)-acrylic acid & Rat in vivo $[92,93]$ \\
\hline & EGC & Rat in vivo $[92,93]$ \\
\hline \multirow{11}{*}{$\begin{array}{c}(+)-G C G \text { or } \\
(-) \text {-EGCG }\end{array}$} & EGC & $\begin{array}{l}\text { Rat in vitro [91]; Human in vitro }[87,88] \\
\text { Pig in vitro }[89]\end{array}$ \\
\hline & Gallic acid & $\begin{array}{c}\text { Rat in vitro [91]; Human in vitro }[87,88] ; \\
\text { Pig in vitro }[89]\end{array}$ \\
\hline & 5-[(3', $4^{\prime}, 5^{\prime}$-trihydroxyphenyl)methyl]oxolan-2-one & Rat in vitro [91]; Pig in vitro [89] \\
\hline & 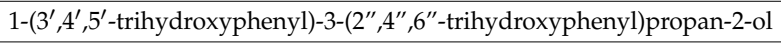 & Rat in vitro [91] \\
\hline & 1-(3',5'-dihydroxyphenyl)-3-(2", $4^{\prime \prime}, 6^{\prime \prime}$ - trihydroxyphenyl)propan-2-ol & Rat in vitro [91] \\
\hline & 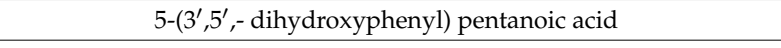 & Rat in vitro [91] \\
\hline & 5-( $3^{\prime}, 4^{\prime}, 5^{\prime}$-trihydroxyphenyl) pentanoic acid & Rat in vitro [91] \\
\hline & 5-(3'-hydroxyphenyl)-pentanoic acid & Rat in vitro [91] \\
\hline & 5-[(3',5'-dihydroxyphenyl)methyl)]oxolan-2-one & Rat in vitro [91] \\
\hline & 3,5-DHPPA & Rat in vitro [91] \\
\hline & 5-[(3', $4^{\prime}, 5^{\prime}$-trihydroxyphenyl)methyl]oxolan-2-one & Human in vitro [87] \\
\hline
\end{tabular}


Table 1. Cont

\begin{tabular}{|c|c|c|}
\hline Compound & Metabolite & $\begin{array}{l}\text { Model (in Vivo/in Vitro) } \\
\text { and References }\end{array}$ \\
\hline \multirow{2}{*}{$\begin{array}{c}(+)-G C G \text { or } \\
(-)-E G C G\end{array}$} & Pyrogallol & Human in vitro [87] \\
\hline & 4-HPAA & Human in vitro [87] \\
\hline \multirow{6}{*}{$(-)-$ EGCG } & EGC & Rat in vivo $[92,93]$ \\
\hline & Gallic acid & Rat in vivo $[92,93]$ \\
\hline & 1-(3',5'-dihydroxyphenyl)-3-(2", $4^{\prime \prime}, 6^{\prime \prime}$-trihydroxyphenyl)propan-2-ol & Rat in vivo $[92,93]$ \\
\hline & 5-[(3', $4^{\prime}, 5^{\prime}$-trihydroxyphenyl)methyl]oxolan-2-one & Rat in vivo $[92,93]$ \\
\hline & 5-[(3',5'-dihydroxyphenyl)methyl)]oxolan-2-one & Rat in vivo $[92,93]$ \\
\hline & 5-[(3', $4^{\prime}$-dihydroxyphenyl)methyl]oxolan-2-one & Rat in vivo $[92,93]$ \\
\hline
\end{tabular}

Abbreviations: 3,4-DHPPA, 3,4-dihydroxyphenylpropionic acid; 3-HPPA, 3-hydroxyphenylpropionic acid; 4-HPPA, 4-hydroxyphenylpropionic acid; 3-HBA, 3-hydroxybenzoic acid; 4-HBA, 4-hydroxybenzoic acid; 3,4-DHPAA, 3,4-dihydroxyphenylacetic acid; 3-HPAA, 3-hydroxyphenylacetic acid; 4-HPAA, 4-hydroxyphenylacetic acid.

\subsubsection{Anthocyanins}

Anthocyanins belong to a large group of secondary plant metabolites collectively known as flavonoids [94]. They are responsible for the red and blue pigmentation of many fruits and vegetables [95]. The health benefits of anthocyanins have been demonstrated in several in vivo and in vitro studies [96-98]. However, the low bioavailability of anthocyanins is a clear obstacle in achieving desired beneficial effects [99].

Several studies on the intestinal absorption of anthocyanins have been reported. The anthocyanins delphinidin 3-O-rutinoside, cyanidin 3-O-rutinoside, delphinidin 3-O-glucoside, and cyanidin 3-O-glucoside were found to be directly absorbed and excreted as the glycosylated forms in both rats and human subjects [100]. A number of studies showed that the proportion of total anthocyanins absorbed and subsequently excreted in urine was far below 1\% [101]. By collecting ileostomy effluent after the consumption of anthocyanin-rich blueberries, Kahle et al. (2006) determined that up to $85 \%$ of blueberry anthocyanins reach the colon under physiological conditions [102]. However, about $69 \%$ of the anthocyanins disappeared from the gastrointestinal tract within $4 \mathrm{~h}$ after food ingestion [103,104]. As demonstrated by in vitro fermentation of anthocyanins seeded by a fecal community obtained from rats, cyanidin-3-glucoside and cyanidin-3-rutinoside extracted from wild mulberry were completely degraded within 10 hours [105]. It is thus likely that intestinal microbiota contribute to the biotransformation and the metabolism of anthocyanins [106].

Fleschhut et al. (2006) incubated an anthocyanin-rich extract from red radish with human fecal suspension in vitro and demonstrated that the first step of the bacterial hydrolysis of anthocyanins (i.e., monoglucosides, diglucosides as well as acylated anthocyanins) involves the cleavage of the sugar moiety leading to the formation of the anthocyanin aglycon. The activities of two bacterial enzymes in particular, $\alpha$,L-rhamnosidase and $\beta, \mathrm{D}$-glucosidase, may be responsible for the deglycosylation of anthocyanins [94]. Due to the high instability of the liberated aglycones at the $\mathrm{pH}$ of various locations in the intestine, they might spontaneously change to form quinoid bases, which further break down into a phenolic acid and an aldehyde via an $\alpha$-diketone intermediate (Figure 4 ). Therefore, the major degradatory pathway of this process is the formation of the phenolic acid descending from the B ring of the anthocyanin skeleton (Table 2) [94,95].

Many studies have shown that protocatechuic acid is one of the most likely major degradation products of anthocyanins. In a human study, Vitaglione et al. (2007) identified that protocatechuic acid was the major metabolite of cyanidin-O-glucosides, accounting for almost $73 \%$ of ingested cyanidin-O-glucosides [101]. After consumption of black raspberries in a porcine model, the phenolic acid profile in the gastrointestinal tract indicated that protocatechuic acid was the major metabolic derivative, followed by $p$-coumaric acid, caffeic acid, ferulic acid and 3-hydroxybenzoic acid [107]. In addition, a high level of protocatechuic 
acid was also identified in rat plasma after the oral intake of cyanidin 3-O- $\beta$-D-glucoside [108]. Cyanidin $3-O-\beta$-D-glucoside was reported to metabolize to protocatechuic acid via cyanidine when incubated with fecal microbiota in an in vitro model. This resulted in a more potent anti-scratching behavioral effect than the parent cyanidin 3-O- $\beta$-D-glucoside in mice, thus suggesting the biological activity of anthocyanins in vivo may increase due to their metabolites, such as phenolic acids [109].

Table 2. The expected B ring fragments for the common anthocyanidins. Reproduced from the original source [110].

\begin{tabular}{cc}
\hline Anthocyanidin & Initial B-Ring Fragmentation Product \\
\hline Pelargonidin & 4-Hydroxybenzoic acid \\
Cyanidin & Protocatechuic acid \\
Delphinidin & Gallic acid \\
Peonidin & Vanillic acid \\
Petunidin & 3-Methoxy-4,5-dihydroxybenzoic acid \\
Malvidin & Syringic acid \\
\hline
\end{tabular}

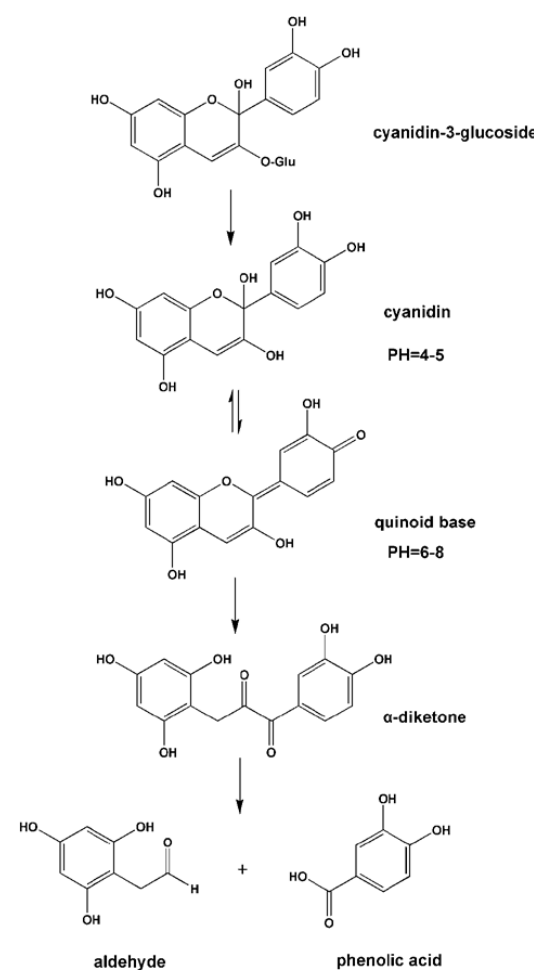

Figure 4. pH-dependent structural changes and degradation of cyanidin-3-glucoside. Reproduced from the original source [94].

\subsection{Nonflavonoid-Type Phenolics}

\subsubsection{Phenolic Acids}

Phenolic acids are found in many foods, and in high concentrations in whole grains, wine and berries. Cereals contain mostly the hydroxycinnamate ferulic acid as a phenolic acid. It is found bound to arabinoxylans by ester bonds in rye. Therefore, esterases (e.g., cinnamoyl estarase) are required during digestion or by the gut microbiota to improve its bioaccessibility [111,112]. As a result of this hydrolysis, unbound phenolic acids can be absorbed through the gastrointestinal barrier and enter peripheral circulation [113].

Moreover, in vitro hydroxycinnamic acid conversions by gut microbiota can be observed. In a study conducted by Gonthier and colleagues (2006), caffeic acid and its esters, caftaric acid and 
chlorogenic acid, were used as a substrate in a human colon model and phenolic acids were transformed into 3-(3'-hydroxyphenyl)propionic acid and minor quantities of benzoic acid. The side-chain shortening of phenylpropionic acid arises through $\beta$-oxidation [114]. Caffeic acid can also be decarboxylated and metabolized into 4-ethylcatechol by gut microbiota [115].

Ferulic acid dimers are other important phenolic acids released from cereals [116]. Two ferulic acids can be bound to each other either through 8-O-4- or 5-5-linkages. In the study of Braune et al. (2009), dehydrodiferulic acid 8-O-4- and 5-5-derivatives were incubated with human fecal microbiota. The 8-O-4 derivative was shown to degrade temporarily to monomeric ferulic acid, which was then biotransformed into 3-( $3^{\prime}, 4^{\prime}$-dihydroxyphenyl)propionic acid, $3^{\prime}, 4^{\prime}$-dihydroxyphenyl acetic acid, 3-phenylpropionic acid, and benzoic acid. An alternative pathway to benzoic acid is related to the metabolism of 3-(4'-hydroxy-3'-methoxyphenyl)pyruvic acid. Contrarily, the 5-5-diferulate derivatives were exposed only to demethylation and/or side-chain reductions [117].

\subsubsection{Stilbenes}

Stilbenoids are very typical polyphenols in our diets, which mainly present in red grapes, wines, cranberries, strawberries, and peanuts $[118,119]$. Resveratrol and its derivatives are the most important dietary stilbenoids associated with many benefits for human health [120-122]. trans-Resveratrol is metabolized by human gut microbiota to dihydroresveratrol, $3,4^{\prime}$-dihydroxy-trans-stilbene and $3,4^{\prime}$-dihydroxybibenzyl (lunularin) in vivo [123]. trans-Piceid, the 3-O- $\beta$-D-glucoside of resveratrol, is metabolized to resveratrol, dihydropiceid and dihydroresveratrol by gut microbiota [124].

\subsubsection{Lignans}

Lignans consist of pinoresinol, matairesinol, secoisolariciresinol, isolariciresinol, syringaresinol and lariciresinol diphenolic compounds with a 1,4-diarylbutane structure [125]. They are mostly found in fruits and vegetables, tea, cereal products, and coffee [126]. If consumed, they are potentially metabolized by microbial processes [2,127-129]. Lignans are considered phytoestrogens because of their estrogen agonist or antagonist properties [2]. The biological activity of lignans is associated with their activation into enterolactone and enterodiol, which are mammalian phytoestrogens [130-132]. The bioavailability of lignans is directly associated with intestinal bacterial metabolism [128]. These biotransformation reactions require demethylation and dehydroxylation [133].

\subsection{Limitations for the Studies on Metabolism of Phenolics and Microbial/Colonic Metabolic Pathways}

By reviewing the latest studies, it can be concluded that phenolic compounds are biotransformed by gut microbiota, generating intermediate and final related metabolites that could be present in the digesta in higher concentrations than their precursors. These phenolic metabolites do not share the same bioavailability and health effects with their parent compounds. In this context, there is an inherent limitation in the studies focused on analyzing the parent compounds in food to correctly estimate the phenomena occurring in the colon. Studies should focus on identifying whether the health benefits are associated with the parent compounds or their phenolic metabolites.

There are also many studies in the literature that observe the biotransformation of phenolic compounds in a food matrix, but studies using pure phenolic compounds are limited. Indeed, food has a complex matrix, and it is difficult to understand the phenolic-gut microbiota interactions directly, as some interactions with other food components might occur. It is important to understand the effect of gut microbiota on pure, individual phenolic compounds.

Another limitation is that it is not clear which intestinal bacteria have an effect on which phenolic compounds. Therefore, it is important to investigate the specific intestinal bacteria implicated in the metabolism of dietary polyphenols.

Phenolic compounds represent a large group, containing many sub-classes, as described. Although they have similar characteristics, there are important differences in their chemical structures, the number of functional groups, and the combination of different moieties, which lead to different 
functional activities. Despite the information obtained and published over recent years, microbial mechanisms of action on each phenolic compound and their metabolites remain unclear, and further research is needed to ascertain causal relationships.

\section{Bioactivity and Bioavailability of Polyphenols are Affected by Gut Microbiota}

Bioaccessibility is an important factor in determining bioavailability, and is a prerequisite for intestinal absorption. The process involves the release of compounds from an encapsulating food matrix that can be solubilized during digestion, and is potentially available for further absorption [7]. Polyphenols exert their functional influence dependent on intestinal absorption. Some polyphenols are found more distributed in nature but may not be bioavailable. The amount of bioaccessible phenolic compounds may differ significantly. Some phenolic compounds may be released and absorbed in small amounts, similar to carotenoids [134]. Some polyphenols, such as anthocyanins, might be degraded before reaching their site of absorption that results in bioaccessibility levels below 10\% [135]. Therefore, a comprehensive understanding of the reactions that occur during digestion is essential to understand and estimate the bioaccessibility of these polyphenols.

Polyphenol structure is an important factor influencing bioavailability. Polyphenols that are most commonly found in dietary components are glycosides (e.g., flavonols, flavones, flavanones, isoflavones and anthocyanins). Less endemic oligomers (proanthocyanidins) are not absorbed by intestinal mucosa [136]. In the intestinal mucosa, only aglycones and some glucosides can be absorbed [137]. Thus, human digestive and microbial enzymes help to release native polyphenols from the food matrix, which is an essential mechanism for them to pass through the intestinal barrier [138,139]. The released aglycones and polyphenol monomers can be transported through passive diffusion and membrane permeases into enterohepatic circulation [136]. There they will be conjugated and returned to the small intestine, along with bile during passage into the liver, mainly by glucuronidation and sulphation reactions. Unabsorbed polyphenols in the small intestine are deconjugated by microbial glucuronidases and sulphatases in the colon, permitting the reuptake of aglycones [140,141]. In addition, intestinal microbiota are able to degrade aglycones and release simple aromatic compounds, including hydroxyphenylacetic acids from flavonols, hydroxyphenyl-propionic acids from flavones and flavanones and phenylvalerolactones and hydroxyphenylpropionic acids from flavanols. This renders them available for subsequent absorption and conjugation [139].

The enveloping food matrix that surrounds polyphenols influences the bioavailability of the molecules. Polyphenols that are integrated into a cellular structure can be released and absorbed in the intestinal mucosa during chewing and food digestion [140,141]. While some foods are consumed unprocessed, many food products require a degree of processing which may alter the bioavailability of phenolic compounds. For example, orange juice processing precipitates flavanones through interactions with pectins and other orange macromolecules, leading to lower bioavailability than the unprocessed phenolic compounds [142]. Furthermore, almond skin polyphenols have lower bioavailability after industrial bleaching [143].

Polyphenols also interact with other nutrients or ingredients that influence their bioavailability. Protein-phenolic interactions generally decrease bioavailability [144], as do associations with dietary fiber [145]. However, lipids seem to enhance the availability of phenolic compounds [146].

Two-way, reciprocal interactions of gut microbiota and phenolic compounds have an important impact on the bioavailability of phenolic compounds and human health. Gut microbiota plays an important role in harvesting nutrients from the diet [147]. Phenolic compounds that are not readily absorbed in the small intestine serve as growth substrates for the members of the gut microbial community, which in turn modify the bioavailability and nutritional properties of these compounds [147]. Phenol Explorer Database Release 2.0 [148] is a useful and capable resource, as it allows rapid retrieval of data on the biotransformations and pharmacokinetics of dietary polyphenols. Pharmacokinetic data on 380 metabolites identified in biofluids after the consumption of polyphenol-rich sources are presented in the database. These data have been extracted from 236 publications, and originate from 221 intervention 
studies in human subjects and experimental animals. This database is important for polyphenol scientists as bioactivities and health effects of polyphenols are dependent on the nature and concentrations of metabolites reaching the target tissues [148]. Higher bioavailability of phenolic compounds, and the resultant beneficial health effects as determined by the consumption of whole grains, vegetables and fruits, can be related to the end-products of microbial metabolism forming short-chain fatty acids such as butyrate, and phenolic acids such as protocatechuic acid [149-152].

In a very recent study by Esposito et al. (2015), the gastrointestinal distribution of black currant anthocyanins and their phenolic acid metabolites were examined in lean and diet-induced obese mice with healthy and antibiotic-disrupted microbiomes. Daily consumption of low-fat or high-fat diet supplemented with $1 \%$ black currant powdered extract (32\% anthocyanins) for eight weeks reduced body weight gain and improved glucose metabolism only in mice with the intact gut microbiome. Administration of antibiotic cocktail resulted in a 16- to 25-fold increase $(p<0.001)$ in the anthocyanin content of feces, and cyanidin-based anthocyanins showed the largest increase in fecal content upon disruption of the gut microbiome, indicating their high susceptibility to microbial degradation in the gut. A three-fold increase in gallic acid over protocatechuic acid was observed in the jejunum of both intact and antibiotic-treated animals, suggesting that this effect was likely independent of gut microbiome status. As a result of this study, it can be concluded that the gut microbiome is necessary for the protective effect of black currant anthocyanins against obesity and the associated insulin resistance [153].

The bioavailability of red raspberry anthocyanins and ellagitannins was studied by Ludwig et al. (2015), considering their biotransformation by gut microbiota. They fed volunteers with red raspberries, containing ellagitannins and cyanidin-based anthocyanins, and analyzed metabolites appearing in plasma and urine by UHPLC-MS. They have indicated that metabolism of anthocyanins appears to start in the upper gastrointestinal tract, possibly $\mathrm{pH}$-initiated, with $4^{\prime}$-hydroxyhippuric acid and ferulic acid derivatives circulating in plasma with a $\mathrm{C}_{\max }$ of 1-1.5 h after consumption of raspberries. Furthermore, formation of these compounds was associated exclusively with the action of the colonic microflora. Ellagitannins pass from the small to the large intestine, where the colonic microbiota mediates the conversion to urolithins A and B. These compounds appeared in plasma and were excreted almost exclusively as sulfate and glucuronide metabolites. The urolithin metabolites persisted in the circulatory system and were excreted in urine for much longer periods of time than the anthocyanin metabolites, although their overall urinary recovery was lower, at $7.0 \%$ of intake. Events that originate in the proximal and distal gastrointestinal tract, and are succeeded by phase II metabolism, play an important role in the bioavailability of both anthocyanins and ellagitannins. Their metabolites, which appear in the circulatory system, are key to elucidating the mode, or modes, of action underlying the protective effects of these compounds on human health [154]. Similar results were obtained in previous bioavailability studies with anthocyanins and ellagitannins [155-158].

An important study explaining the effect of altered gut microbiota on the bioavailability of phenolics, performed by Dudonne et al. (2015), investigated the bioavailability of cranberry phenolics after oral administration of a cranberry extract (CE) to high-fat, high-sucrose (HFHS)-fed mice. Their work explored the possible modulation of gut microbiota composition following a co-supplementation with spores of Bacillus subtilis CU1 probiotic (CE/P). They extracted and characterized phenolic metabolites from plasma using $\mu$ SPE-UHPLC-MS/MS, and a metagenomic analysis was performed on feces to assess gut bacterial composition. Twenty-two circulating metabolites were identified, mainly microbial degradation products of native cranberry phenolic compounds. Plasma concentration of three microbial metabolites was significantly increased with the CE/P co-treatment: $p$-coumaric acid, $m$-coumaric acid and $p$-hydroxybenzoic acid $(+53 \%,+103 \%$ and $+70 \%$, respectively). They reported significant differences in the proportion of Barnesiella and Oscillibacter genera in CE/P-treated mice in comparison with control animals. This study pointed out that altered gut microbiota has a significant effect on the degradation and bioavailability of phenolic compounds in mice [159].

In contrast, it has been proposed that high concentrations of phenolic compounds could exert potential health benefits within the gastrointestinal tract [160]. Choy et al. (2013) studied the 
bioavailability of proanthocyanidins after ingestion of grape seed extract. Their findings indicate that ingested polymeric proanthocyanidins were present in the colon as the intact parent compounds and thus may contribute to the health of the gastrointestinal tract [161]. The same finding was reported previously, as in studies by He et al. (2005) that showed that high levels of anthocyanins in fecal content may play an important role in colonic health [162].

In summary, recent literature demonstrates that the mutual relationship between gut microbiota and phenolic compounds increases the bioavailability of phenolics and provides increased health benefits. Phenolic compounds can alter the gut microbiota community, resulting in a greater abundance of beneficial microbes, and a consequent increase in bioavailability. At the same time, phenolic compounds are biotransformed into their smaller metabolites by gut microbiota, which also contributes to increased bioavailability. The persistence of larger, intact phenolic compounds such as proanthocyanidins in the colon would allow these compounds to exert local beneficial biological actions, particularly on colonic epithelial cells, resulting in protective effects against inflammation-mediated diseases including colorectal cancer.

\section{Polyphenols Modulate the Gut Microbiota Composition}

Several phenolic compounds have been recognized as potential antimicrobial agents with bacteriostatic or bactericidal actions. In addition, they also inhibit bacterial infections of intestinal and urinary tract epithelia. Selma et al. (2009) reviewed the influence of human intestinal bacteria on health and the incidence of disease [42]. Gut health is mainly determined by the complex interactions between host and gastrointestinal microbiota. Beneficial bacteria such as Bifidobaterium spp. and Lactobacillus spp. have been observed to contribute to human health at different levels [163]. They enhance gut barrier function, stimulate the host immune system, prevent diarrhea or allergies, contribute to activation of provitamins, and modulate lipid metabolism [163,164]. However, there are other bacterial species associated with negative implications, such as Clostridium difficile, which has been associated with inflammatory bowel disease [165]. Therefore, it is of crucial importance to understand the inhibitory or stimulatory effect of phenolic compounds on beneficial or pathogenic bacteria, and their ratio in the gut. The influence of phenolic compounds on gut microbiota is provided in detail (Table 3).

\subsection{Flavonoid-Type Phenolics}

\subsubsection{Flavonols}

Duda Chodak (2012) studied the impact of flavonols (i.e., quercetin and rutin) on specific intestinal microbial species. In this study, six bacteria species (Bacteroides galacturonicus, Lactobacillus sp., Enterococcus caccae, Bifidobacterium catenulatum, Ruminococcus gauvreauii, and Escherichia coli) were inoculated with pure flavonols at final concentrations of 4,20, and $50 \mu \mathrm{g} / \mathrm{mL}$ of quercetin and at 20, 100 , and $250 \mu \mathrm{g} / \mathrm{mL}$ of rutin. Interestingly, quercetin showed a dose-dependent inhibitory effect on the growth of all analyzed bacterial species, whereas this effect was weaker for rutin [166].

Etxeberria et al. (2015) investigated whether quercetin administration could reverse the gut microbiota community attributable to a high-fat and high-carbohydrate diet and thereby impact health. Quercetin supplementation resulted in an altered composition of gut microbiota at different taxonomic levels, including the relative Firmicutes: Bacteroidetes ratio and inhibiting the growth of bacterial species associated with diet-induced obesity such as Erysipelotrichaceae, Bacillus spp., and Eubacterium cylindroides [167].

In an in vitro study conducted by Kawabata and colleagues (2013), Bifidobacterium adolescentis, a commensal often isolated from the human intestine was incubated with different flavonols (i.e., quercetin, myricetin, galangin, kaempferol, and fisetin) to evaluate the effects of flavonols on the growth of $B$. adolescentis. Although galangin inhibited the growth of B. adolescentis by $30 \%-70 \%$ when co-cultured for 1-6 h, quercetin and fisetin showed no or little effect on the growth rate $(20 \%$ 
inhibition at $6 \mathrm{~h}$ ). Their study revealed that the tested flavonols, except for galangin, have no or weak anti-bacterial activity against $B$. adolescentis [168].

\subsubsection{Flavones and Flavanones}

In a study by Parkar et al. (2008), many different polyphenols were demonstrated to influence the growth of human gut bacteria and their adhesion to enterocytes. Accordingly, naringenin promoted the growth of Lactobacillus rhamnosus, commensal Escherichia coli, along with two pathogens, Staphylococcus aureus and Salmonella typhimurium. In general, the Gram-positive enteropathogen S. aureus was the most sensitive to naringenin, while the Gram-negative pathogen S. typhimurium and the commensal organism E. coli were likely to be similar in their sensitivity to naringenin [169].

Moreover, Duda Chodak (2012) also studied the impact of naringenin and hesperetin on six bacteria species (Bacteroides galacturonicus, Lactobacillus sp., Enterococcus caccae, Bifidobacterium catenulatum, Ruminococcus gauvreauii, and Escherichia coli) and found out that they inhibited the growth of almost all analyzed bacteria (MIC $\geqslant 250 \mu \mathrm{g} / \mathrm{mL})$ [166].

\subsubsection{Isoflavones}

Isoflavones are transformed by gut microbiota, although there are few studies regarding the effect of isoflavone supplementation on gut microbiota composition. Parkar et al. (2008) investigated isoflavones (e.g., daidzein and genistein) on the growth of microbiota. As such, isoflavones induced a decrease in bacterial growth [168]. In another study by Clavel et al. (2005), postmenopausal women were supplemented with isoflavones (100 mg/day) for two months. As a result of the supplementation, it was observed that isoflavones changed predominant bacterial populations with enrichment of the Clostridium coccoides-Eubacterium rectale (Erec) cluster, Faecalibacterium prasnutzii subgroup, and Lactobacillus-Enterococcus group. The increased concentrations of the Erec cluster were proposed to be related with an intestinal metabolite from a daidzein named equol [170].

\subsubsection{Flavanols}

Tzosunis et al. (2008) investigated the reciprocal metabolic interactions between gut microbiota and (-)-epicatechin and (+)-catechin using a pH-controlled, stirred, batch-culture fermentation system to model the distal colon. Interestingly, $(+)$-catechin influenced the growth of specific bacterial populations, including a statistically significant increase in the Clostridium coccoides-Eubacterium rectale group, Bifidobacterium spp. and Escherichia coli, as well as inhibiting the growth of the Clostridium histolyticum group. In contrast, (-)-epicatechin proved to be less active, only significantly increasing the C. coccoides-Eubacterium rectale group. These potential prebiotic effects for both $(+)$-catechin and (-)-epicatechin were most notable at a low concentration of $150 \mathrm{mg} / \mathrm{L}$. As both (-)-epicatechin and (+)-catechin were converted to the same metabolites, the more dramatic change in the growth of distinct commensal populations produced by $(+)$-catechin incubation may be linked to the bacterial conversion of $(+)$-catechin to (-)-epicatechin. In summary, these data suggest that the consumption of flavanol-rich foods may support gut health through their ability to exert prebiotic actions [171].

In the study of Cueva et al. (2013), two flavan-3-ol fractions were used to investigate the in vitro fermentation with bacterial populations monitored by fluorescent in situ hybridization correlated with the appearance of phenolic metabolites. Both flavanol fractions promoted the growth of Lactobacillus/Enterococcus and decreased the C. histolyticum group during fermentation. Together, these data suggest that flavan-3-ol modulates microbiota composition and inherent catabolic activity, inducing changes that could affect the bioavailability and potential bioactivity of these compounds [172].

In an in vivo study done by Choy et al. (2014), six crossbred female pigs were fed with a diet containing grape seed extract for six days. DNA was extracted from pig fecal samples and the V3/V4 region of the 16S rRNA gene was sequenced using an Illumina MiSeq. The results indicated that the diet containing grape seed extract resulted in modulation of the gut microbiome, dramatically increasing Lachnospiraceae, Clostridiales, Lactobacillus and Ruminococcaceae. They have reported that the 
relationship between dietary proanthocyanidins and colon health may be attributed to the modulation of gut microbiota [173].

\subsubsection{Anthocyanins}

Hidalgo et al. (2012) investigated the bacterial metabolism of malvidin-3-glucoside, gallic acid and a mixture of anthocyanins using an in vitro model of the human gut. The anthocyanins universally enhanced the growth of Bifidobacterium spp. and Lactobacillus-Enterococcus spp. significantly. This suggests that anthocyanins and their metabolites may positively select for beneficial members of the gut microbial community. Interestingly, malvidin-3-glucoside mixed with other anthocyanins exhibited a synergistic effect in promoting beneficial microbes [174].

Ultimately, there are very few in vitro, animal, and human intervention studies of anthocyanin interactions with gut microbiota. Thus, it is difficult to compare results and synthesize a conclusion, due in part to the varying techniques used to study microbiota, the different sources of anthocyanins, and study designs. Clearly, further research is necessary to clarify if anthocyanins have a direct or indirect effect on beneficial/pathogenic bacteria growth.

\subsection{Nonflavonoid-Type Phenolics}

\subsubsection{Phenolic Acids}

In the study performed by Hidalgo et al. (2012), in vitro incubation of gallic acid in a fecal slurry reduced a group of potentially harmful bacteria such as Clostridium histolyticum without any negative effects on beneficial bacteria. In addition, it significantly reduced Bacteroides spp. growth and enhanced both the total bacterial number and the abundance of Atopobium spp. [174].

In another study, the influence of hydroxycinnamic acids such as caffeic acid, chlorogenic acid, $o$-coumaric acid, $p$-coumaric acid on the growth of a probiotic microbe (Lactobacillus rhamnosus), a commensal (Escherichia coli) and two pathogenic bacteria (Staphylococcus aureus, Salmonella typhimurium) was investigated. They compared the MIC values of all polyphenols tested and observed that flavonols, isoflavones and glycosides have a low antibacterial activity, while phenolic acids were found to be at an intermediate level. On the other hand, the flavanone and flavanol tested had high antibacterial activity [169].

\subsubsection{Hydrolyzable Tannins (Ellagitannins)}

Ellagitannins are hydrolyzable tannins that are hydrolyzed in vivo to release ellagic acid. They produce urolithin when they are metabolized by the gut microbiota. The effect of these tannins on the growth of intestinal bacteria is inadequately characterized, and generally their antimicrobial potential has been assessed in vitro.

In an in vitro study conducted by Bialonska et al. (2009), the effect of a commercial pomegranate extract at a concentration of $0.01 \%$ as well as the effect of its main constituents $(0.05 \%)$ on the growth of several species of human gut bacteria using a liquid culturing method was investigated. As a result of this study, it was observed that pomegranate byproducts and punicalagins inhibited the growth of pathogenic Clostridia and Staphylococcus aureus. Interestingly, probiotic Lactobacilli and Bifidobacteria were generally not affected by ellagitannins [175]. It is important to note that Bialonska et al. (2010) intended to prove whether this trend was maintained using a fermentation batch-culture system inoculated with fecal samples from healthy individuals, which better simulates conditions from the colonic region. In this experiment, pomegranate extract was able to produce an incremental increase on total bacterial number, enhancing the growth of Bifidobacterium spp., Lactobacillus and Enterococcus groups, while no effect was observed for the C. histolyticum group [176].

In the study of Larrosa et al. (2010), the ellagitanins of pomegranate and their main microbiotaderived metabolite urolithin A have also been identified to be responsible for changes in intestinal microbiota in rats with an increase of Bifidobacterium and Lactobacillus levels [177]. 
A different in vivo study, Li et al. (2015) had 20 healthy volunteers consume $1000 \mathrm{mg}$ of pomegranate extract (POM) for four weeks. Changes in gut microbiota composition were monitored. Three distinct groups were established according to the urinary and fecal content of the POM metabolite urolithin A (UA). These groups were classified as (1) individuals with no baseline UA presence but induction of UA formation by POM extract consumption $(n=9)$; (2) baseline UA formation which was enhanced by POM extract consumption $(n=5)$; and (3) no baseline UA production, which was not inducible $(n=6)$. According to the results, Actinobacteria was increased and Firmicutes decreased significantly in individuals forming UA (producers). Additionally, Verrucomicrobia (Akkermansia muciniphila) was 33- and 47-fold higher in stool samples of UA producers compared to non-producers at baseline and after four weeks, respectively. In UA producers, the genera Butyrivibrio, Enterobacter, Escherichia, Lactobacillus, Prevotella, Serratia and Veillonella increased in abundance, and Collinsella decreased significantly at week 4 compared to the baseline. The consumption of POM extract resulted in the formation of its metabolites in some but not all participants. POM extract consumption may induce health benefits secondary to changes in the microbiota [178].

\subsubsection{Stilbenes}

The antimicrobial effects of resveratrol (3,5,4'-trihydroxy-trans-stilbene) against several pathogenic and beneficial bacteria have been reported. In the in vivo study of Larrosa et al. (2009), rats were fed with $1 \mathrm{mg}$ of resveratrol $/ \mathrm{kg} /$ day (a human-equivalent dose) for 25 days, and in the last five days, $5 \%$ dextran sulfate sodium (DSS) was administered to induce colitis. Effects on colon tissue damage, gut microbiota, reactive oxygen species, inflammatory markers and nitric oxide production as well as gene expression profile with microarrays were evaluated. Resveratrol increased lactobacilli and bifidobacteria as well as diminished the increase of enterobacteria upon DSS treatment [179].

In another study of Qiao et al. (2014), mice were supplemented by resveratrol (200 $\mathrm{mg}$ per $\mathrm{kg}$ per day) and the changes in gut microbiota were monitored and quantified by fluorescence in situ hybridization and flow cytometry methods. Results of this study showed that resveratrol ameliorates the dysbiosis in the gut microbiota induced by the high-fat diet, specific effects including an increase in the Bacteroidetes-to-Firmicutes ratio, significant inhibition of the growth of Enterococcus faecalis, and increased growth of Lactobacillus and Bifidobacterium [180].

Etxeberria et al. (2015) determined whether trans-resveratrol administration could affect gut microbiota modulation produced by a high-fat sucrose (HFS) diet, thereby improving gut health. Trans-resveratrol supplementation significantly reduced the mean relative abundance of different Clostridia species such as Clostridium aldenense (-93.1\%), Clostridium hathewayi $(-73.2 \%)$, Clostridium sp. C9 $(-76.3 \%)$ and Clostridium sp. MLG661 (-53.7\%). This data is in opposition to the mean relative abundance of Clostridium sp. XB90 (266.6\%) which was notably enhanced when compared to the HFS-diet-fed control rats. Additionally, the percentage of change in the mean relative abundance of Gracilibacter thermotolerans $(-57.7 \%)$ and Parabacteroides distasonis $(-77.4 \%)$ was negatively affected by trans-resveratrol in comparison to that detected in the HFS-diet-fed control group. Moreover, trans-resveratrol supplementation produced a statistically significant inhibition in the Graciibacteraceae family $(-57.7 \%)$ compared to the HFS-diet-fed control rats. As a result of this study, it is stated that trans-resveratrol supplementation alone or in combination with quercetin almost modified the profile of gut bacteria, but instead acted at the intestinal level [167].

\subsubsection{Lignans}

In the study of Niemi et al. (2013), a lignin-rich fraction originating from brewers' spent grain did not suppress the conversion activity of gut microbiota in an in vitro colon metabolic model, nor did it inhibit the growth of beneficial gut bacteria, lactobacilli and bifidobacteria [180]. Moreover, some component in the protease-alkaline extracted fraction enabled the growth of bifidobacteria for a longer time than glucose [181]. 
Table 3. Influence of phenolic compounds in gut microbiota composition.

\begin{tabular}{|c|c|c|c|c|c|c|c|}
\hline Polyphenol Type & Tested Bacteria & $\begin{array}{c}\text { Growth (+)/Inhibitory } \\
(-) \text { Effect }\end{array}$ & Type of Study & Methods Used & Duration & Doses & References \\
\hline \multicolumn{8}{|c|}{ IN VITRO CELL CULTURE STUDIES } \\
\hline \multicolumn{8}{|l|}{ Flavonols } \\
\hline \multicolumn{8}{|l|}{ Quercetin } \\
\hline & Bacteroides galacturonicus & $(-)$ & In vitro & Counting on culture medium & $24 \mathrm{~h}$ & 4,20 or $50 \mu \mathrm{g} / \mathrm{mL}$ & [166] \\
\hline & Lactobacillus sp. & $(-)$ & & & & & \\
\hline & Enterococcus caccae & $(-)$ & & & & & \\
\hline & Bifidobacterium catenulatum & $(-)$ & & & & & \\
\hline & Ruminococcus gauvreauii & $(-)$ & & & & & \\
\hline & Escherichia coli & $(-)$ & & & & & \\
\hline Rutin & & & & & \multicolumn{3}{|c|}{20,100 or $250 \mu \mathrm{g} / \mathrm{mL}$} \\
\hline & Bacteroides galacturonicus, & NS & & & & & \\
\hline & Lactobacillus sp. & $(+)$ & & & & & \\
\hline & Enterococcus caccae & NS & & & & & \\
\hline & Bifidobacterium catenulatum & $(-)$ & & & & & \\
\hline & Ruminococcus gauvreauii & NS & & & & & \\
\hline & Escherichia coli & $(-)$ & & & & & \\
\hline Flavonols & Bifidobacterium adolescentis & & In vitro & Counting on culture medium & $24 \mathrm{~h}$ & \multirow{6}{*}{$\begin{array}{c}\text { flavonol } \\
\text { (galangin,kaempferol, } \\
\text { quercetin, myricetin, or } \\
\text { fisetin dissolved in } \\
\text { dimethylsulphoxide } \\
\text { (DMSO); final } 25 \mu \mathrm{M} \text {; final } \\
0.1 \% \text { DMSO }\end{array}$} & [168] \\
\hline Galangin & & $(-)$ & & & & & \\
\hline Kaempferol & & NS & & & & & \\
\hline Quercetin & & NS & & & & & \\
\hline Myricetin & & NS & & & & & \\
\hline Fisetin & & NS & & & & & \\
\hline$\underline{\text { Isoflavones }}$ & & $\operatorname{MIC}(\mu \mathrm{g} / \mathrm{mL})$ & In vitro & $\begin{array}{c}\text { Minimum Inhibitory } \\
\text { Concentration Assay (MIC) }\end{array}$ & $1 \mathrm{~h}$ & $\begin{array}{l}\text { Concentrations ranging } \\
\text { from } 62.5 \text { to } 1000 \mu \mathrm{g} / \mathrm{mL}\end{array}$ & [170] \\
\hline \multirow[t]{4}{*}{ Daidzein } & Eschericia coli & 1000 & & & & & \\
\hline & Staphylococcus aureus & 125 & & & & & \\
\hline & Salmonella typhimirum & 1000 & & & & & \\
\hline & Lactobacillus rhamnosus & 1000 & & & & & \\
\hline \multirow[t]{4}{*}{ Genistein } & Eschericia coli & 1000 & & & & & \\
\hline & Staphylococcus aureus & 125 & & & & & \\
\hline & Salmonella typhimirum & 1000 & & & & & \\
\hline & Lactobacillus rhamnosus & 1000 & & & & & \\
\hline
\end{tabular}


Table 3. Cont

\begin{tabular}{|c|c|c|c|c|c|c|c|}
\hline Polyphenol Type & Tested Bacteria & $\begin{array}{c}\text { Growth (+)/Inhibitory } \\
(-) \text { Effect }\end{array}$ & Type of Study & Methods Used & Duration & Doses & References \\
\hline Flavanones & & MIC $(\mu \mathrm{g} / \mathrm{mL})$ & In vitro & $\begin{array}{c}\text { Minimum Inhibitory } \\
\text { Concentration Assay (MIC) }\end{array}$ & $1 \mathrm{~h}$ & $\begin{array}{l}\text { Concentrations ranging } \\
\text { from } 62.5 \text { to } 1000 \mu \mathrm{g} / \mathrm{mL}\end{array}$ & [169] \\
\hline \multirow[t]{4}{*}{ Naringenin } & Eschericia coli & 125 & & & & & \\
\hline & Staphylococcus aureus & 62.5 & & & & & \\
\hline & Salmonella typhimirum & 125 & & & & & \\
\hline & Lactobacillus rhamnosus & 125 & & & & & \\
\hline Phenolic acids & & MIC $(\mu \mathrm{g} / \mathrm{mL})$ & In vitro & $\begin{array}{c}\text { Minimum Inhibitory } \\
\text { Concentration Assay (MIC) }\end{array}$ & $1 \mathrm{~h}$ & $\begin{array}{l}\text { Concentrations ranging } \\
\text { from } 62.5 \text { to } 1000 \mu \mathrm{g} / \mathrm{mL}\end{array}$ & [169] \\
\hline \multirow[t]{4}{*}{ caffeic acid } & Eschericia coli & 500 & & & & & \\
\hline & Staphylococcus aureus & 125 & & & & & \\
\hline & Salmonella typhimirum & 500 & & & & & \\
\hline & Lactobacillus rhamnosus & $\leqslant 250$ & & & & & \\
\hline \multirow[t]{4}{*}{ chlorogenic acid } & Eschericia coli & 1000 & & & & & \\
\hline & Staphylococcus aureus & 125 & & & & & \\
\hline & Salmonella typhimirum & 1000 & & & & & \\
\hline & Lactobacillus rhamnosus & $\leqslant 250$ & & & & & \\
\hline \multirow[t]{4}{*}{$o$-coumaric acid } & Eschericia coli & 250 & & & & & \\
\hline & Staphylococcus aureus & 125 & & & & & \\
\hline & Salmonella typhimirum & 250 & & & & & \\
\hline & Lactobacillus rhamnosus & 250 & & & & & \\
\hline \multirow[t]{4}{*}{$p$-coumaric acid } & Eschericia coli & 500 & & & & & \\
\hline & Staphylococcus aureus & 125 & & & & & \\
\hline & Salmonella typhimirum & 500 & & & & & \\
\hline & Lactobacillus rhamnosus & 500 & & & & & \\
\hline Ellagitannins & $\underline{\mathrm{POMx}}$ & & In vitro & Liquid culturing method & POMx (100 mL) & $\begin{array}{l}\text { comercial extract of } \\
\text { pomegranate at } 0.01 \% \text { as } \\
\text { well as the effect of its } \\
\text { main constituents }(0.05 \%)\end{array}$ & [175] \\
\hline \multirow{8}{*}{$\begin{array}{l}\text { Extract of pomegranate } \\
\text { (POMx) and its } \\
\text { main constituents } \\
\text { (punicalagins, punicalins, } \\
\text { elagic acid, gallic acid) }\end{array}$} & L. acidophilus & $(+)$ & & & & & \\
\hline & L. casei ssp. casei & NS & & & & & \\
\hline & L. paracasei ssp. & NS & & & & & \\
\hline & L. pentosus & $(+)$ & & & & & \\
\hline & L. rhamnosus & $(+)$ & & & & & \\
\hline & B. breve & $(+)$ & & & & & \\
\hline & B. infantis & $(+)$ & & & & & \\
\hline & B. longum & NS & & & & & \\
\hline
\end{tabular}


Table 3. Cont.

\begin{tabular}{|c|c|c|c|c|c|c|c|}
\hline Polyphenol Type & Tested Bacteria & $\begin{array}{c}\text { Growth (+)/Inhibitory } \\
(-) \text { Effect }\end{array}$ & Type of Study & Methods Used & Duration & Doses & References \\
\hline \multirow{35}{*}{$\begin{array}{l}\text { Extract of pomegranate } \\
\text { (POMx) and its } \\
\text { main constituents } \\
\text { (punicalagins, punicalins, } \\
\text { elagic acid, gallic acid) }\end{array}$} & B. bifidum & $(+)$ & & & & & \\
\hline & B. animalis ssp. lactis & NS & & & & & \\
\hline & Bacteroides fragilis & NS & & & & & \\
\hline & C. perfringens & $(-)$ & & & & & \\
\hline & Clostridium clostriidoforme & NS & & & & & \\
\hline & C. ramosum & $(-)$ & & & & & \\
\hline & S. aureus & $(-)$ & & & & & \\
\hline & Punicalagin & & & & & & \\
\hline & L. acidophilus & NS & & & & & \\
\hline & L. casei ssp. casei & NS & & & & & \\
\hline & L. paracasei ssp. & NS & & & & & \\
\hline & L. pentosus & NS & & & & & \\
\hline & L. rhamnosus & NS & & & & & \\
\hline & B. breve & $(+)$ & & & & & \\
\hline & B. infantis & NS & & & & & \\
\hline & B. longum & NS & & & & & \\
\hline & B. bifidum & NS & & & & & \\
\hline & B. animalis ssp. lactis & $(+)$ & & & & & \\
\hline & Bacteroides fragilis & NS & & & & & \\
\hline & C. perfringens & $(-)$ & & & & & \\
\hline & Clostridium clostriidoforme & $(-)$ & & & & & \\
\hline & C. ramosum & $(-)$ & & & & & \\
\hline & S. aureus & $(-)$ & & & & & \\
\hline & Punicalin & & & & & & \\
\hline & $\overline{\text { L. acidophilus }}$ & NS & & & & & \\
\hline & L. casei ssp. casei & NS & & & & & \\
\hline & L. paracasei ssp. & NS & & & & & \\
\hline & L. pentosus & NS & & & & & \\
\hline & L. rhamnosus & NS & & & & & \\
\hline & B. breve & NS & & & & & \\
\hline & B. infantis & NS & & & & & \\
\hline & B. longum & NS & & & & & \\
\hline & B. bifidum & NS & & & & & \\
\hline & B. animalis ssp. lactis & $(+)$ & & & & & \\
\hline & Bacteroides fragilis & NS & & & & & \\
\hline
\end{tabular}


Table 3. Cont

\begin{tabular}{|c|c|c|c|c|c|c|c|}
\hline Polyphenol Type & Tested Bacteria & $\begin{array}{c}\text { Growth (+)/Inhibitory } \\
(-) \text { Effect }\end{array}$ & Type of Study & Methods Used & Duration & Doses & References \\
\hline \multirow{4}{*}{$\begin{array}{l}\text { Extract of pomegranate } \\
\text { (POMx) and its main } \\
\text { constituents } \\
\text { (punicalagins, punicalins, } \\
\text { elagic acid, gallic acid) }\end{array}$} & C. perfringens & NS & & & & & \\
\hline & Clostridium clostriidoforme & NS & & & & & \\
\hline & C. ramosum & NS & & & & & \\
\hline & S. aureus & NS & & & & & \\
\hline \multicolumn{8}{|c|}{ IN VITRO FAECAL MICROBIOTA STUDIES } \\
\hline Flavonols & Erysipelotrichaceae & $(-)$ & In vitro & $16 \mathrm{~S}$ rDNA reads & 6 weeks & $30 \mathrm{mg} / \mathrm{kg}$ BW/day & [167] \\
\hline \multirow[t]{29}{*}{ Quercetin } & Ruminococcaceae & NS & & & & & \\
\hline & Clostridiaceae & NS & & & & & \\
\hline & Bacteroidaceae & NS & & & & & \\
\hline & Lachnospiraceae & NS & & & & & \\
\hline & Acidaminococcaceae & NS & & & & & \\
\hline & Eubacteriaceae & NS & & & & & \\
\hline & Prevotellaceae & NS & & & & & \\
\hline & Acholeplasmataceae & NS & & & & & \\
\hline & Lactobacillaceae & NS & & & & & \\
\hline & Graciibacteraceae & NS & & & & & \\
\hline & Clostridium aldenense & NS & & & & & \\
\hline & Clostridium hathewayi & NS & & & & & \\
\hline & Bacteroides vulgatus & $(+)$ & & & & & \\
\hline & Clostridium clariflavum & $(+)$ & & & & & \\
\hline & Clostridium methylpentosum & NS & & & & & \\
\hline & Clostridium sp. C9 & NS & & & & & \\
\hline & Clostridium sp. XB90 & NS & & & & & \\
\hline & Clostridium sp. MLG661 & $(+)$ & & & & & \\
\hline & Blautia stercoris & NS & & & & & \\
\hline & Gracilibacter thermotolerans & NS & & & & & \\
\hline & Parabacteroides distansonis & NS & & & & & \\
\hline & Eubacterium cylindroides & $(-)$ & & & & & \\
\hline & Akkermansia muciniphila & NS & & & & & \\
\hline & Bilophila wadsworthia & NS & & & & & \\
\hline & Bacteroides sp. dnLKV7 & NS & & & & & \\
\hline & Barnesiella intestinihominis & NS & & & & & \\
\hline & Bacteroides sp. S-18 & NS & & & & & \\
\hline & Bacteroides chinchillae & NS & & & & & \\
\hline & Candidatus Prevotella conceptionensis & NS & & & & & \\
\hline
\end{tabular}


Table 3. Cont

\begin{tabular}{|c|c|c|c|c|c|c|c|}
\hline Polyphenol Type & Tested Bacteria & $\begin{array}{c}\text { Growth (+)/Inhibitory } \\
(-) \text { Effect }\end{array}$ & Type of Study & Methods Used & Duration & Doses & References \\
\hline Flavanols & & & & & $10 \mathrm{~h}(150 \mathrm{mg} / \mathrm{L})$ & $150 \mathrm{mg} / \mathrm{L}$ and $1000 \mathrm{mg} / \mathrm{L}$ & [171] \\
\hline \multirow[t]{6}{*}{ (+)-catechin } & Bifidobacterium spp. & $(+)$ & & & $17 \mathrm{~h}(1000 \mathrm{mg} / \mathrm{L})$ & $150 \mathrm{mg} / \mathrm{L}$ and $1000 \mathrm{mg} / \mathrm{L}$ & \\
\hline & Bacteroides spp. & NS & & & & & \\
\hline & Lactobacillus/Enterococcus spp. & NS & & & & & \\
\hline & $\begin{array}{l}\text { Clostridium coccoides- Eubacterium } \\
\text { rectale group }\end{array}$ & $(+)$ & & & & & \\
\hline & C. histolyticum group & $(-)$ & In vitro & $\begin{array}{c}\text { Fluorescent in situ } \\
\text { hybridization (FISH) }\end{array}$ & & & \\
\hline & Escherichia coli & $(+)$ & & & & & \\
\hline \multicolumn{8}{|l|}{ (-)-epicatechin } \\
\hline & Bifidobacterium spp. & NS & & & & & \\
\hline & Bacteroides spp. & NS & & & & & \\
\hline & Lactobacillus/Enterococcus spp. & NS & & & & & \\
\hline & $\begin{array}{c}\text { Clostridium coccoides- Eubacterium } \\
\text { rectale group }\end{array}$ & $(+)$ & & & & & \\
\hline & C. histolyticum group & NS & & & & & \\
\hline & Escherichia coli & NS & & & & & \\
\hline$\underline{\text { Flavan-3-ols }}$ & Lactobacillus/Enterococcus & $(+)$ & In vitro & $\begin{array}{c}\text { Fluorescent in situ } \\
\text { hybridization (FISH) }\end{array}$ & $\begin{array}{c}\text { Samples were } \\
\text { collected at } 0,5,10, \\
24,30 \text { and } 48 \mathrm{~h} \text { of } \\
\text { fermentation }\end{array}$ & $600 \mathrm{mg} / \mathrm{L}$ & [172] \\
\hline 2 fractions of grape seed & Clostridium histolyticum & $(-)$ & $\begin{array}{l}\text { Human fecal } \\
\text { microbiota }\end{array}$ & & & & \\
\hline Anthocyanins & & & In vitro & $\begin{array}{c}\text { Fluorescent in situ } \\
\text { hybridization (FISH) }\end{array}$ & $\begin{array}{c}0,1,2,4,5,10, \text { and } \\
24 \mathrm{~h}\end{array}$ & $20 \mathrm{mg} / \mathrm{L}$ and $200 \mathrm{mg} / \mathrm{L}$ & [174] \\
\hline \multirow[t]{7}{*}{ Malvidin-3-glucoside } & Total bacteria count & $(+)$ & & & & & \\
\hline & Atopobium spp. & $(+)$ & & & & & \\
\hline & Bif idobacterium spp. & $(+)$ & & & & & \\
\hline & C. cocoides-Eubacterium rectale & $(+)$ & & & & & \\
\hline & Bacteroides spp. & $(-)$ & & & & & \\
\hline & Lactobacillus spp. & $(+)$ & & & & & \\
\hline & Clostridium histolyticum & $(-)$ & & & & & \\
\hline
\end{tabular}


Table 3. Cont

\begin{tabular}{|c|c|c|c|c|c|c|c|}
\hline Polyphenol Type & Tested Bacteria & $\begin{array}{c}\text { Growth (+)/Inhibitory } \\
(-) \text { Effect }\end{array}$ & Type of Study & Methods Used & Duration & Doses & References \\
\hline Stilbenes & Erysipelotrichaceae & NS & In vitro & $16 \mathrm{~S}$ rDNA reads & 6 weeks & $15 \mathrm{mg} / \mathrm{kg}$ BW/day & [167] \\
\hline \multirow[t]{29}{*}{ Trans-resveratrol } & Ruminococcaceae & NS & & & & & \\
\hline & Clostridiaceae & NS & & & & & \\
\hline & Bacteroidaceae & NS & & & & & \\
\hline & Lachnospiraceae & NS & & & & & \\
\hline & Acidaminococcaceae & NS & & & & & \\
\hline & Eubacteriaceae & NS & & & & & \\
\hline & Prevotellaceae & NS & & & & & \\
\hline & Acholeplasmataceae & NS & & & & & \\
\hline & Lactobacillaceae & NS & & & & & \\
\hline & Graciibacteraceae & $(-)$ & & & & & \\
\hline & Clostridium aldenense & $(-)$ & & & & & \\
\hline & Clostridium hathewayi & $(-)$ & & & & & \\
\hline & Bacteroides vulgatus & NS & & & & & \\
\hline & Clostridium clariflavum & NS & & & & & \\
\hline & Clostridium methylpentosum & NS & & & & & \\
\hline & Clostridium sp. C9 & $(-)$ & & & & & \\
\hline & Clostridium sp. XB90 & $(+)$ & & & & & \\
\hline & Clostridium sp. MLG661 & $(-)$ & & & & & \\
\hline & Blautia stercoris & NS & & & & & \\
\hline & Gracilibacter thermotolerans & $(-)$ & & & & & \\
\hline & Parabacteroides distansonis & $(-)$ & & & & & \\
\hline & Eubacterium cylindroides & NS & & & & & \\
\hline & Akkermansia muciniphila & NS & & & & & \\
\hline & Bilophila wadsworthia & NS & & & & & \\
\hline & Bacteroides sp. dnLKV7 & NS & & & & & \\
\hline & Barnesiella intestinihominis & NS & & & & & \\
\hline & Bacteroides sp. S-18 & NS & & & & & \\
\hline & Bacteroides chinchillae & NS & & & & & \\
\hline & Candidatus Prevotella conceptionensis & NS & & & & & \\
\hline
\end{tabular}


Table 3. Cont

\begin{tabular}{|c|c|c|c|c|c|c|c|}
\hline Polyphenol Type & Tested Bacteria & $\begin{array}{c}\text { Growth (+)/Inhibitory } \\
(-) \text { Effect }\end{array}$ & Type of Study & Methods Used & Duration & Doses & References \\
\hline Phenolic acids & Total bacteria count & $(+)$ & In vitro & $\begin{array}{c}\text { Fluorescent in situ } \\
\text { hybridization (FISH) }\end{array}$ & $\begin{array}{c}0,1,2,4,5,10 \text {, and } \\
24 \mathrm{~h}\end{array}$ & $150 \mathrm{mg} / \mathrm{L}$ and $1000 \mathrm{mg} / \mathrm{L}$ & [174] \\
\hline \multirow[t]{6}{*}{ Gallic acid } & Atopobium spp. & $(+)$ & & & & & \\
\hline & Bif idobacterium spp. & $(+)$ & & & & & \\
\hline & C. cocoides-Eubacterium rectale & $(+)$ & & & & & \\
\hline & Bacteroides spp. & $(-)$ & & & & & \\
\hline & Lactobacillus spp. & $(+)$ & & & & & \\
\hline & Clostridium histolyticum & $(-)$ & & & & & \\
\hline$\underline{\text { Ellagitannins }}$ & Total bacteria & $(+)$ & In vitro & $\begin{array}{l}\text { batch-culture fermentation } \\
\text { system inoculated with fecal } \\
\text { samples from healthy } \\
\text { individuals, FISH }\end{array}$ & $\begin{array}{l}\text { Samples collected at } \\
0,5,10,24 \text { and } 48 \mathrm{~h}\end{array}$ & $\begin{array}{c}\text { POMx }(1.5 \mathrm{~mL}) \text { and } \\
\text { punicalagins }(250 \mathrm{mg}) \\
\text { were inoculated in stirring } \\
\text { batch-culture vessels (one } \\
\text { per treatment) containing } \\
\text { faecal slurry }(1: 10, w / v) .\end{array}$ & [175] \\
\hline \multirow[t]{4}{*}{$\begin{array}{l}\text { pomegranate by-product } \\
\text { (POMx) }\end{array}$} & Bifidobacterium spp. & $(+)$ & & & & & \\
\hline & Lactobacillus spp. & $(+)$ & & & & & \\
\hline & $\begin{array}{l}\text { Clostridium coccoides-Eubacterium } \\
\text { rectale group C. histolyticum group }\end{array}$ & $(+)$ & & & & & \\
\hline & & NS & & & & & \\
\hline Lignans & Lactobacillus rhamnosus VTT E-97800 & $(+)$ & $\begin{array}{l}\text { In vitro colon } \\
\text { model }\end{array}$ & Counting on culture medium & $0,2,4,6,8$, and $24 \mathrm{~h}$ & $\begin{array}{c}8 \mathrm{~mL} \text { of fecal suspension, } \\
\text { and a } 16.7 \%(w / v) \text { final } \\
\text { concentration of fresh } \\
\text { fecal matter }\end{array}$ & [179] \\
\hline \multirow[t]{6}{*}{ Lignins } & L. rhamnosus VTT E-97948 & $(+)$ & & & & & \\
\hline & Lactobacillus paracasei VTT E-97949 & $(+)$ & & & & & \\
\hline & Lactobacillus salivarius VTT E-981006 & $(+)$ & & & & & \\
\hline & $\begin{array}{c}\text { Bifidobacterium adolescentis VTT } \\
\text { E-981074, Bifidobacterium breve VTT } \\
\text { E-981075, Bifidobacterium longum VTT } \\
\text { E-96664 }\end{array}$ & $(+)$ & & & & & \\
\hline & Lactobacillus rhamnosus VTT E-97800, & $(+)$ & & & & & \\
\hline & L. rhamnosus VTT E-97948 & $(+)$ & & & & & \\
\hline \multicolumn{8}{|c|}{ IN VIVO STUDIES } \\
\hline Isoflavones & $\begin{array}{c}\text { Clostridium coccoides-Eubacterium } \\
\text { rectale cluster }\end{array}$ & $(+)$ & In vivo & $\begin{array}{l}\text { FISH and flow cytometry } \\
\text { analyses }\end{array}$ & $\begin{array}{l}2 \text { months (Fecal } \\
\text { samples were } \\
\text { collected on day } 0 \text {, } \\
30 \text {, and } 60 \text { ) }\end{array}$ & $\begin{array}{l}100 \mathrm{mg} / \text { day of } \\
\text { isoflavones aglycon } \\
\text { equivalents }\end{array}$ & [170] \\
\hline & Lactobacillus-Enterococcus group, & $(+)$ & & & & & \\
\hline & $\begin{array}{c}\text { Faecalibacterium prausnitzii subgroup, } \\
\text { Bifidobacterium genus }\end{array}$ & $(+)$ & & & & & \\
\hline
\end{tabular}


Table 3. Cont.

\begin{tabular}{|c|c|c|c|c|c|c|c|}
\hline Polyphenol Type & Tested Bacteria & $\begin{array}{c}\text { Growth (+)/Inhibitory } \\
(-) \text { Effect }\end{array}$ & Type of Study & Methods Used & Duration & Doses & References \\
\hline & $\begin{array}{c}\text { Clostridium coccoides-Eubacterium } \\
\text { rectale cluster }\end{array}$ & $(+)$ & & & & & \\
\hline Condensed Tannins & Lachnospiraceae & $(+)$ & In vivo & $\begin{array}{c}\text { culture-independent } \\
\text { barcoded next generation } \\
\text { sequencing }\end{array}$ & 3 days normal diet & $\begin{array}{c}1 \% \mathrm{w} / \mathrm{w} \text { Grape Seed } \\
\text { Extract }\end{array}$ & [173] \\
\hline \multirow[t]{3}{*}{ Proanthocyanidins } & Clostridiales & $(+)$ & & & $\begin{array}{c}6 \text { days treatment } \\
\text { diet }\end{array}$ & & \\
\hline & Lactobacillus & $(+)$ & & & $\begin{array}{c}3 \text { days post } \\
\text { treatment } \\
\text { control-feeding }\end{array}$ & & \\
\hline & Ruminococcaceae & $(+)$ & & & $\begin{array}{l}\text { fecessamples taken } \\
\text { daily }\end{array}$ & & \\
\hline$\underline{\text { Stilbenes }}$ & & & In vivo & Agar dilution method & 25 days & $1 \mathrm{mg} / \mathrm{kg} /$ day & [179] \\
\hline \multirow{3}{*}{$\overline{\text { Resveratrol }}$} & Lactobacillus & $(+)$ & & & & & \\
\hline & Bifidobacterium & $(+)$ & & & & & \\
\hline & Enterobacteria & Diminished the increase & & & & & \\
\hline Stilbenes & Bacteroidetes-to-Firmicutes ratio, & $(+)$ & In vivo & FISH and flow cytometry & 12 weeks & $200 \mathrm{mg} / \mathrm{kg} /$ day & [180] \\
\hline \multirow[t]{3}{*}{ Resveratrol } & Enterococcus faecalis & $(-)$ & & & & & \\
\hline & Lactobacillus & $(+)$ & & & & & \\
\hline & Bifidobacterium & $(+)$ & & & & & \\
\hline Ellagitannins & Lactobacilli & $(+)$ & In vivo & $\begin{array}{l}\text { Agar dilution method with } \\
\text { fecal microbiota of rats }\end{array}$ & $\begin{array}{c}\text { Samples collected at } \\
\text { days } 0,10,20\end{array}$ & $250 \mathrm{mg} / \mathrm{kg} /$ day & [177] \\
\hline $\begin{array}{c}\text { Pomegranate } \\
\text { ellagitannins and their } \\
\text { microbiota-derived } \\
\text { metabolite urolithin A }\end{array}$ & Bifidobacterium & $(+)$ & & & & & \\
\hline Ellagitannins & Actinobacteria & $(+)$ & In vivo & FISH and flow cytometry & 4 weeks & 1000 mg POM extract & [178] \\
\hline \multirow[t]{10}{*}{$\begin{array}{c}\text { Pomegranate (POM) } \\
\text { ellagitannins }\end{array}$} & Firmicutes & $(-)$ & & & & & \\
\hline & $\begin{array}{l}\text { Verrucomicrobia (Akkermansia } \\
\text { muciniphila) }\end{array}$ & $(+)$ & & & & & \\
\hline & Butyrivibrio & $(+)$ & & & & & \\
\hline & Enterobacter & $(+)$ & & & & & \\
\hline & Eschericia & $(+)$ & & & & & \\
\hline & Lactobacillus & $(+)$ & & & & & \\
\hline & Prevotella & $(+)$ & & & & & \\
\hline & Serratia & $(+)$ & & & & & \\
\hline & Veillonella & $(+)$ & & & & & \\
\hline & Collinsella & $(-)$ & & & & & \\
\hline
\end{tabular}

NS: no significant difference, (+): increase, (-): decrease. 


\subsection{Limitations for the Studies on Gut Microbiota Composition Modulation by Polyphenols}

The effect of phenolic compounds on gut microbiota modulation has gained much attention in recent years, but the influence of polyphenols on specific gut bacteria is still not clear. One of the main limitations in previous studies is that most phenolic fractions and pure phenolic compounds have been analyzed without considering the bioavailability and the chemistry of phenolic compounds in the colon.

Another limitation is that the information obtained from in vitro studies about the role of individual phenolic compounds on gut microbiota cannot be directly extrapolated to what occurs in the physiological context of the gut ecosystem. Human and animal intervention studies involve very high doses of individual phenolic compounds, or high amounts of foods rich in phenolic content, neither of which represents the regular diet. Therefore, there is a lack of adequate in vivo studies.

Human intervention studies provide the best models for studying the effect of phenolic compounds on gut microbiota modulation. However, in vivo human intervention studies hold inevitable practical and ethical limitations. Few studies have observed the in vivo impact of phenolic compounds on the human gut microbiota [170,173,177-180]. Of those performed, most were focused on single polyphenol molecules and selected bacterial populations. Further in vivo research is needed to understand the effect of phenolic compounds on gut microbiota.

There may be a wide variability in response to phenolic compounds according to the differences in gut microbiota composition. It is difficult to understand the relationship between phenolic compounds and gut microbiota according to these inter-individual differences, especially if there are different diet-microbiota relations. Future studies should be done considering the inter-individual differences in gut microbiota while studying effect of phenolic compounds on gut microbiota modulation from the immunological point of view.

After a thorough review of the latest studies on the effect of phenolic compounds on gut microbiota, it can be stated that phenolic compounds and their metabolites contribute to beneficial gastrointestinal health effects by modulating gut microbial balance with the simultaneous inhibition of pathogens and stimulation of beneficial bacteria. These latest studies indicate that the concept of prebiotics is not limited to non-digestible carbohydrates, but also applies to phenolic compounds that have the ability to show prebiotic action $[9,48,168,171,177]$. Therefore, the regular consumption of phenolic compound-rich foods in a diet may beneficially balance the gut microbiota and exert beneficial health effects.

\section{Conclusions}

The interactions between dietary components, especially phenolic compounds and gut microbiota, have gained much attention due to their relevance to bioavailability and human health. Even though there are a number of important studies on this topic, the data presented in these papers are generally focused on the one-way relationship between phenolics and gut microbiota, or on bioavailability. On the other hand, this review presents an overview of the reciprocal relationship of all the subclasses of phenolic compounds and gut microbiota, as well as the relevance of these interactions to bioavailability and human health.

When the studies are investigated, it is clear that there are some limitations and problems with respect to the present applications and results. For example, the studies presented in the literature largely investigated the biotransformation of phenolic compounds in a food matrix. However, studies using pure phenolic compounds are lacking, making it difficult to understand the exact mechanism of each individual compound. On the other hand, phenolic compounds are biotransformed by gut microbiota generating phenolic metabolites which may have different bioavailability in comparison to their parent compounds. Moreover, there are some limitations for the in vivo studies including ethical and economical issues, their complicated nature during application, and difficulties in translating the in vitro data into in vivo conditions. 
Apart from the concerns noted above, studies focusing on the effect of two-way mutual interactions between gut microbiota and phenolic compounds are critical, as these results may lead to new information with respect to health. Indeed, future studies are still required to understand this complicated mechanism. The fact that phenolic compounds may balance the gut microbiota and contribute to gastrointestinal health, and may indeed exert prebiotic activity, makes it clear that it is important to clarify these mechanisms specifically to understand which bacteria will affect which phenolic compounds.

Acknowledgments: The authors thank Rachel Levantovsky for assisting with revising the manuscript.

Author Contributions: Tugba Ozdal was primarily responsible for manuscript preparation. Esra Capanoglu, David A. Sela, Jianbo Xiao, Dilek Boyacioglu, and Fang Chen contributed to critical discussions and approved the final version of the manuscript.

Conflicts of Interest: The authors declare no conflict of interest.

\section{Abbreviations}

$\begin{array}{ll}\text { 3,4-DHPPA } & \text { 3,4-dihydroxyphenylpropionic acid } \\ \text { 3-HPPA } & \text { 3-hydroxyphenylpropionic acid } \\ \text { 4-HPPA } & \text { 4-hydroxyphenylpropionic acid } \\ \text { 3-HBA } & \text { 3-hydroxybenzoic acid } \\ \text { 4-HBA } & \text { 4-hydroxybenzoic acid } \\ \text { 3,4-DHPPA } & \text { 3,4-dihydroxyphenylacetic acid } \\ \text { 3-HPAA } & \text { 3-hydroxyphenylacetic acid } \\ \text { 4-HPAA } & \text { 4-hydroxyphenylacetic acid } \\ \text { FISH } & \text { fluorescent in situ hybridisation }\end{array}$

\section{References}

1. Vinson, J.A.; Su, X.; Zubik, L.; Bose, P. Phenol antioxidant quantity and quality in foods: Fruits. J. Agric. Food Chem. 2001, 49, 5315-5321. [CrossRef] [PubMed]

2. Scalbert, A.; Manach, C.; Morand, C.; Remesy, C.; Jimenez, L. Dietary polyphenols and the prevention of diseases. Crit. Rev. Food Sci. Nutr. 2005, 45, 287-306. [CrossRef] [PubMed]

3. Khurana, S.; Venkataraman, K.; Hollingsworth, A.; Piche, M.; Tai, T.C. Polyphenols: Benefits to the cardiovascular system in health and in ageing. Nutrients 2013, 5, 3779-3827. [CrossRef] [PubMed]

4. Meydani, M.; Hasan, S.T. Dietary polyphenols and obesity. Nutrients 2010, 2, 737-751. [CrossRef] [PubMed]

5. Li, A.-N.; Li, S.; Zhang, Y.-J.; Xu, X.-R.; Chen, Y.-M.; Li, H.-B. Resources and biological activities of natural polyphenols. Nutrients 2014, 6, 6020-6047. [CrossRef] [PubMed]

6. Manach, C.; Williamson, G.; Morand, C.; Scalbert, A.; Remesy, C. Bioavailability and bioefficacy of polyphenols in humans. I. Review of 97 bioavailability studies. Am. J. Clin. Nutr. 2005, 81, 230-242.

7. Parada, J.; Aguilera, J.M. Food microstructure affects the bioavailability of several nutrients. J. Food Sci. 2007, 72, 21-32. [CrossRef] [PubMed]

8. Scalbert, A.; Williamson, G. Dietary intake and bioavailability of polyphenols. J. Nutr. 2000, 130, $2073-2085$.

9. Lee, H.C.; Jenner, A.M.; Low, C.S.; Lee, Y.K. Effect of tea phenolics and their aromatic fecal bacterial metabolites on intestinal microbiota. Res. Microbiol. 2006, 157, 876-884. [CrossRef] [PubMed]

10. Van Duynhoven, J.; Vaughan, E.E.; Jacobs, D.M.; Kemperman, R.A.; van Velzen, E.J.J.; Gross, G.; Roger, L.C.; Possemiers, S.; Smilde, A.K.; Doré, J.; et al. Metabolic fate of polyphenols in the human superorganism. Proc. Natl. Acad. Sci. USA 2011, 108, 4531-4538. [CrossRef] [PubMed]

11. Mosele, J.; Macià, A.; Motilva, M.-J. Metabolic and microbial modulation of the large intestine ecosystem by non-absorbed diet phenolic compounds: A review. Molecules 2015, 20, 17429-17468. [CrossRef] [PubMed]

12. Moco, S.; Martin, F.P.J.; Rezzi, S. Metabolomics view on gut microbiome modulation by polyphenol-rich foods. J. Proteome Res. 2012, 11, 4781-4790. [CrossRef] [PubMed] 
13. Tuohy, K.M.; Conterno, L.; Gasperotti, M.; Viola, R. Up-regulating the human intestinal microbiome using whole plant foods, polyphenols, and/or fiber. J. Agric. Food Chem. 2012, 60, 8776-8782. [CrossRef] [PubMed]

14. Valdés, L.; Cuervo, A.; Salazar, N.; Ruas-Madiedo, P.; Gueimonde, M.; González, S. The relationship between phenolic compounds from diet and microbiota: Impact on human health. Food Funct. 2015, 6, 2424-2439. [CrossRef] [PubMed]

15. Duda-Chodak, A.; Tarko, T.; Satora, P.; Sroka, P. Interaction of dietary compounds, especially polyphenols, with the intestinal microbiota: A review. Eur. J. Nutr. 2015, 54, 325-341. [CrossRef] [PubMed]

16. Dueñas, M.; Muñoz-González, I.; Cueva, C.; Jiménez-Girón, A.; Sánchez-Patán, F.; Santos-Buelga, C.; Moreno-Arribas, M.V.; Bartolome, B. A survey of modulation of gut microbiota by dietary polyphenols. Biomed. Res. Int. 2015, 2015, 1-15.

17. He, X.; Marco, M.L.; Slupsky, C.M. Emerging aspects of food and nutrition on gut microbiota. J. Agric. Food Chem. 2013, 61, 9559-9574. [CrossRef] [PubMed]

18. Possemiers, S.; Bolca, S.; Verstraete, W.; Heyerick, A. The intestinal microbiome: A separate organ inside the body with the metabolic potential to influence the bioactivity of botanicals. Fitoterapia 2011, 82, 53-66. [CrossRef] [PubMed]

19. Alminger, M.; Aura, A.M.; Bohn, T.; Dufour, C.; El, S.N.; Gomes, A.; Karakaya, S.; Martines-Cuesta, M.C.; McDougall, G.J.; Requena, T.; et al. In vitro models for studying secondary plant metabolite digestion and bioaccessibility. Compr. Rev. Food Sci. Food Saf. 2014, 13, 413-436. [CrossRef]

20. Puupponen-Pimiä, R.; Aura, A.M.; Oksman-Caldentey, K.M.; Myllärinen, P.; Saarela, M.; Mattila-Sandholm, T.; Poutenen, K. Development of functional ingredients for gut health. Trends Food Sci. Technol. 2002, 13, 3-11. [CrossRef]

21. Chen, D.; Wan, S.B.; Yang, H.; Yuan, J.; Chan, T.H.; Dou, Q.P. EGCG, green tea polyphenols and their synthetic analogs and prodrugs for human cancer prevention and treatment. Adv. Clin. Chem. 2011, 53, 155-177. [PubMed]

22. Weng, C.J.; Yen, G.C. Chemopreventive effects of dietary phytochemicals against cancer invasion and metastasis: Phenolic acids, monophenol, polyphenol and their derivatives. Cancer Treat. Rev. 2012, 38, 76-87. [CrossRef] [PubMed]

23. Kuriyama, S.; Shimazu, T.; Ohmori, K.; Kikuchi, N.; Nakaya, N.; Nishino, Y.; Tsubono, Y.; Tsuji, I. Green tea consumption and mortality due to cardiovascular disease, cancer and all causes in Japan. J. Am. Med. Assoc. 2006, 296, 1255-1265. [CrossRef] [PubMed]

24. Mursu, J.; Voutilainen, S.; Nurmi, T.; Tuomainen, T.P.; Kurt, S.; Salonen, J.T. Flavonoid intake and the risk of ischaemic stroke and CVD mortality in middle-ages Finnish men. J. Nutr. 2008, 100, 890-895. [CrossRef] [PubMed]

25. Jeong, W.Y.; Jin, J.S.; Cho, Y.A.; Lee, J.H.; Park, S.; Jeong, S.W.; Kim, Y.-H.; Lim, C.-S.; El-Aty, A.M.; Kim, G.-S.; et al. Determination of polyphenols in three Capsicum annuum L. (bell pepper) varieties using high-performance liquid chromatography-tandem mass spectrometry: Their contribution to overall antioxidant and anticancer activity. J. Sep. Sci. 2011, 34, 2967-2974. [CrossRef] [PubMed]

26. Ogunleye, A.A.; Xue, F.; Michels, K.B. Green tea consumption and breast cancer risk or recurrence: A meta-analysis. Breast Cancer Res. Treat. 2009, 119, 477-484. [CrossRef] [PubMed]

27. Liu, L.; Zubik, L.; Collins, F.W.; Marko, M.; Meydani, M. The antiatherogenic potential of oat phenolic compounds. Atherosclerosis 2004, 175, 39-49. [CrossRef] [PubMed]

28. Mulvihill, E.E.; Huff, M.W. Antiatherogenic properties of flavonoids: Implications for cardiovascular health. Can. J. Cardiol. 2010, 26, 17-21. [CrossRef]

29. Zakaria, Z.A.; Hisam, E.E.A.; Rofiee, M.S.; Norhafizah, M.; Somchit, M.N.; Teh, L.K.; Salleh, M.Z. In vivo antiulcer activity of the aqueous extract of Bauhinia purpurea leaf. J. Ethnopharmacol. 2011, 137, 1047-1054. [CrossRef] [PubMed]

30. Han, N.; Gu, Y.; Ye, C.; Cao, Y.; Liu, Z.; Yin, J. Antithrombotic activity of fractions and components obtained from raspberry leaves (Rubus chingii). Food Chem. 2012, 132, 181-185. [CrossRef] [PubMed]

31. Tao, W.W.; Duan, J.A.; Yang, N.Y.; Tang, Y.P.; Liu, M.Z.; Qian, Y.F. Antithrombotic phenolic compounds from Glycyrrhiza uralensis. Fitoterapia 2012, 83, 422-425. [CrossRef] [PubMed] 
32. Beara, I.N.; Lesjak, M.M.; Orcic, D.Z.; Simin, N.D.; Cetoyevic-Simin, D.D.; Bozin, B.; Mimica-Dukic, N.M. Comparative analysis of phenolic profile, antioxidant, anti-inflammatory and cytotoxic activity of two closely-related plantain species: Plantago altissima L. and Plantago lanceolata L. LWT Food Sci. Technol. 2012, 47, 64-70. [CrossRef]

33. Zimmer, A.R.; Leonardi, B.; Miron, D.; Schapoval, E.; Oliveira, J.R.; Gosmann, G. Antioxidant and anti-inflammatory properties of Capsicum baccatum: From traditional use to scientific approach. J. Ethnopharmacol. 2012, 139, 228-233. [CrossRef] [PubMed]

34. Chung, S.Y.; Champagne, E.T. Reducing the allergenic capacity of peanut extracts and liquid peanut butter by phenolic compounds. Food Chem. 2009, 115, 1345-1349. [CrossRef]

35. Schmitz-Eiberger, M.A.; Blanke, M.M. Bioactive components in forced sweet cherry fruit (Prunus avium L.) antioxidative capacity and allergenic potential as dependent on cultivation under cover. LWT Food Sci. Technol. 2012, 46, 388-392. [CrossRef]

36. Bijak, M.; Bobrowski, M.; Borowiecka, M.; Podsędek, A.; Golański, J.; Nowak, P. Anticoagulant effect of polyphenols-rich extracts from black chokeberry and grape seeds. Fitoterapia 2011, 82, 811-817. [CrossRef] [PubMed]

37. Schütz, K.; Saß, M.; With, A.; Graubaum, H.J.; Grünwald, J. Immunemodulating efficacy of a polyphenol-rich beverage on symptoms associated with the common cold: A double-blind, randomised, placebo-controlled, multi-centric clinical study. Br. J. Nutr. 2010, 104, 1156-1164. [CrossRef] [PubMed]

38. Silva, J.C.; Rodrigues, S.; Feas, X.; Estevinho, L.M. Antimicrobial activity, phenolic profile and role in the inflammation of propolis. Food Chem. Toxicol. 2012, 50, 1790-1795. [CrossRef] [PubMed]

39. Xia, D.; Wu, X.; Shi, J.; Yang, Q.; Zhang, Y. Phenolic compounds from the edible seeds extract of Chinese Mei (Prunus mume Sieb. Et Zucc) and their antimicrobial activity. LWT Food Sci. Technol. 2011, 44, 347-349. [CrossRef]

40. Mudnic, I.; Modun, D.; Rastija, V.; Vukovic, J.; Brizic, I.; Katalinic, V.; Kozina, B.; Medic-Saric, M.; Boban, M. Antioxidant and vasodilatory effects of phenolic acids in wine. Food Chem. 2010, 119, 1205-1210. [CrossRef]

41. Santoz, M.D.; Almeida, M.C.; Lopez, N.P.; Souza, G.E.P. Evaluation of the anti-inflammatory, analgesic and antipyretic activities of the natural polyphenols CGA. Biol. Pharm. Bull. 2010, 29, 2236-2240. [CrossRef]

42. Selma, M.V.; Espín, J.C.; Tomás-Barberán, F.A. Interaction between phenolics and gut microbiota: Role in human health. J. Agric. Food. Chem. 2009, 57, 6485-6501. [CrossRef] [PubMed]

43. Faria, A.; Fernandes, I.; Norberto, S.; Mateus, N.; Calhau, C. Interplay between anthocyanins and gut microbiota. J. Agric. Food Chem. 2014, 62, 6898-6902. [CrossRef] [PubMed]

44. Guinane, C.M.; Cotter, P.D. Role of the gut microbiota in health and chronic gastrointestinal disease: Under-standing a hidden metabolic organ. Ther. Adv. Gastroenterol. 2013, 6, 295-308. [CrossRef] [PubMed]

45. Cani, P.D.; Delzenne, N.M. The role of the gut microbiota in energy metabolism and metabolic disease. Curr. Pharm. Des. 2009, 15, 1546-1558. [CrossRef] [PubMed]

46. Qin, J.; Li, R.; Raes, J.; Arumugam, M.; Burgdorf, K.S.; Manichanh, C.; Nielsen, T.; Pons, N.; Levenez, F.; Yamada, T.; et al. A human gut microbial gene catalogue established by metagenomic sequencing. Nature 2010, 464, 59-65. [CrossRef] [PubMed]

47. Arboleya, S.; Binetti, A.; Salazar, N.; Fernandez, N.; Solis, G.; Hernandez-Barranco, A.; Margolles, A.; de los Reyes-Gavilan, C.G.; Gueimonde, M. Establishment and development of intestinal microbiota in preterm neonates. FEMS Microbiol. Ecol. 2012, 79, 763-772. [CrossRef] [PubMed]

48. Tzounis, X.; Rodriguez-Mateos, A.; Vulevic, J.; Gibson, G.R.; Kwik-Uribe, C.; Spencer, J.P. Prebiotic evaluation of cocoa-derived flavanols in healthy humans by using a randomized, controlled, double-blind, crossover intervention study. Am. J. Clin. Nutr. 2011, 93, 62-72. [CrossRef] [PubMed]

49. Queipo-Ortuño, M.I.; Boto-Ordóñez, M.; Murri, M.; Gomez-Zumaquero, J.M.; Clemente-Postigo, M.; Estruch, R.; Diaz, F.C.; Andres-Lacueva, C.; Tinahones, F.J. Influence of red wine polyphenols and ethanol on the gut microbiota ecology and biochemical biomarkers. Am. J. Clin. Nutr. 2012, 95, 1323-1334. [CrossRef] [PubMed]

50. Rastmanesh, R. High polyphenol, low probiotic diet for weight loss because of intestinal microbiota interaction. Chem. Biol. Interact. 2011, 189, 1-8. [CrossRef] [PubMed]

51. Hervert-Hernandez, D.; Goñi, I. Dietary polyphenols and human gut microbiota: A review. Food. Rev. Int. 2011, 27, 154-169. [CrossRef] 
52. Laparra, J.M.; Sanz, Y. Interactions of gut microbiota with functional food components and nutraceuticals. Pharmacol. Res. 2010, 61, 219-225. [CrossRef] [PubMed]

53. Gotteland, M.; Andrews, M.; Toledo, M.; Muñoz, L.; Caceres, P.; Anziani, A.; Wittig, E.; Speisky, H.; Salazar, G. Modulation of Helicobacter pylori colonization with cranberry juice and Lactobacillus johnsonii La1 in children. Nutrition 2008, 24, 421-426. [CrossRef] [PubMed]

54. Vitali, B.; Ndagijimana, M.; Cruciani, F.; Carnevali, P.; Candela, M.; Guerzoni, M.E.; Brigidi, P. Impact of a synbiotic food on the gut microbial ecology and metabolic profiles. BMC Microbiol. 2010, 10, 4. [CrossRef] [PubMed]

55. Hollman, P.C.; Katan, M.B. Dietary flavonoids: Intake, health effects and bioavailability. Food Chem. Toxicol. 1999, 37, 937-942. [CrossRef]

56. Winter, J.; Moore, L.H.; Dowell, V.R.; Bokkenheuser, V.D. C-Ring cleavage of flavonoids by human Intestinal bacteria. Appl. Environ. Microbiol. 1989, 55, 1203-1208. [PubMed]

57. Winter, J.; Popoff, M.R.; Grimont, P.; Bokkenheuser, V.D. Clostridium orbiscindens sp. Nov., a human intestinal bacterium capable of cleaving the flavonoid C-ring. Int. J. Syst. Bacteriol. 1991, 41, 355-357. [CrossRef] [PubMed]

58. Rechner, A.R.; Smith, M.A.; Kuhnle, G.; Gibson, G.R.; Debnam, E.S.; Srai, S.K.S.; Moore, K.P.; Rice-Evans, C.A. Colonic metabolism of dietary polyphenol: Influence of structure on microbial fermentation products. Free Radic. Biol. Med. 2004, 36, 212-225. [CrossRef] [PubMed]

59. Toma's-Barbera'n, F.A.; Clifford, M.N. Flavanones, chalcones and dihydrochalcones nature, occurrence and dietary burden. J. Sci. Food Agric. 2000, 80, 1073-1080. [CrossRef]

60. Robards, K.; Li, X.; Antolovich, M.; Boyd, S. Characterisation of citrus by chromatographic analysis of flavonoids. J. Sci. Food Agric. 1997, 75, 87-101. [CrossRef]

61. Xiao, J.B. Dietary flavonoid aglycones and their glycosides: What show better biological benefits? Crit. Rev. Food Sci. Nutr. 2016. [CrossRef]

62. Xiao, J.B.; Högger, P. Dietary polyphenols and type 2 diabetes: Current insights and future perspectives. Curr. Med. Chem. 2015, 22, 23-38. [CrossRef] [PubMed]

63. Xiao, J.B.; Capanoglu, E.; Jassbi, A.R.; Miron, A. Advance on the flavonoid C-glycosides and health benefits. Crit. Rev. Food Sci. Nutr. 2015. [CrossRef] [PubMed]

64. Zhang, Y.; Tie, X.W.; Bao, B.L.; Wu, X.Q.; Zhang, Y. Metabolism of flavone C-glucosides and p-coumaric acid from antioxidant of bamboo leaves (AOB) in rats. Br. J. Nutr. 2007, 97, 484-494. [CrossRef] [PubMed]

65. Yuan, J.; Wang, J.; Liu, X. Metabolism of dietary soy isoflavones to equol by human intestinal microflora; implications for health. Mol. Nutr. Food Res. 2007, 51, 765-781. [CrossRef] [PubMed]

66. Sarkar, F.H.; Li, Y.W. Mechanisms of cancer chemoprevention by soy isoflavone genistein. Cancer Metastasis Rev. 2002, 21, 265-280. [CrossRef] [PubMed]

67. Messina, M. Soyfoods and soybean phyto-oestrogens (isoflavones) as possible alternatives to hormone replacement therapy (HRT). Eur. J. Cancer 2000, 36, 71-77. [CrossRef]

68. Cornwell, T.; Cohick, W.; Raskin, I. Dietary phytoestrogens and health. Phytochemistry 2004, 65, 995-1016. [CrossRef] [PubMed]

69. Setchell, K.D.R.; Brown, N.M.; Zimmer-Nechemias, L.; Brashear, W.T.; Wolfe, B.; Kirscher, A.S.; Heubi, J.E. Evidence for lack of absorption of soy isoflavone glycosides in humans, supporting the crucial role of intestinal metabolism for bioavailability. Am. J. Clin. Nutr. 2002, 76, 447-453. [PubMed]

70. Linford, N.J.; Dorsa, D.M. $17 \beta$-Estradiol and the phytoestrogen genistein attenuate neuronal apoptosis induced by the endoplasmic reticulum calcium-ATPase inhibitor thapsigargin. Steroids 2002, 67, 1029-1040. [CrossRef]

71. Setchell, K.D.R.; Brown, N.M.; Lydeking-Olsen, E. The clinical importance of the metabolite equol-A clue to the effectiveness of soy and its isoflavones. J. Nutr. 2002, 32, 3577-3584.

72. Zubik, L.; Meydani, M. Bioavailability of soybean isoflavones from aglycone and glucoside forms in American women. Am. J. Clin. Nutr. 2003, 77, 1459-1465. [PubMed]

73. Hur, H.; Rafii, F. Biotransformation of the isoflavonoids biochanin A, formononetin and glycitein by Eubacterium limosum. FEMS Microbiol. Lett. 2000, 192, 21-25. [CrossRef] [PubMed]

74. Simons, A.L.; Renouf, M.; Hendrich, S.; Murphy, P.A. Metabolism of glycitein (7; $4^{\prime}$-dihydroxy6-methoxy-isoflavone) by human gut microflora. J. Agric. Food Chem. 2005, 53, 8519-8525. [CrossRef] [PubMed] 
75. Heinonen, S.; Hoikkala, A.; Wahala, K.; Adlercreutz, H. Metabolism of the soy isoflavones daidzein, genistein and glycitein in human subjects. Identification of new metabolites having an intact isoflavonoid skeleton. J. Steroid Biochem. Mol. Biol. 2003, 87, 285-299. [CrossRef] [PubMed]

76. Kuhnle, G.; Spencer, J.P.; Schroeter, H.; Shenoy, B.; Debnam, E.S.; Srai, S.K.; Rice-Evans, C.; Hahn, U. Epicatechin and catechin are $\mathrm{O}$-methylated and glucuronidated in the small intestine. Biochem. Biophys. Res. Commun. 2000, 277, 507-512. [CrossRef] [PubMed]

77. Vaidyanathan, J.B.; Walle, T. Glucuronidation and sulfation of the tea flavonoid (-)-epicatechin by the human and rat enzymes. Drug Metab. Dispos. 2002, 30, 897-890. [CrossRef] [PubMed]

78. Hackman, R.M.; Polagruto, J.A.; Zhu, Q.Y.; Sun, B.; Fujii, H.; Keen, C.L. Flavanols: Digestion, absorption and bioactivity. Phytochem. Rev. 2008, 7, 195-208. [CrossRef]

79. Garcıá-Ramirez, B.; Fernández-Larrea, J.; Salvado, M.J.; Ardevol, A.; Arola, L.; Blade, C. Tetramethylated dimeric procyanidins are detected in rat plasma and liver early after oral administration of synthetic oligomeric procyanidins. J. Agric. Food Chem. 2006, 54, 2543-2551. [CrossRef] [PubMed]

80. Deprez, S.; Brezillon, C.; Rabot, S.; Philippe, C.; Mila, I.; Lapierre, C.; Scalbert, A. Polymeric proanthocyanidins are catabolized by human colonic microflora into low-molecular-weight phenolic acids. J. Nutr. 2000, 130, 2733-2738. [PubMed]

81. Rios, L.Y.; Gonthier, M.P.; Remesy, C.; Mila, I.; Lapierre, C.; Lazarus, S.A.; Williamson, G.; Scalbert, A. Chocolate intake increases urinary excretion of polyphenol-derived phenolic acids in healthy human subjects. Am. J. Clin. Nutr. 2003, 77, 912-918. [PubMed]

82. Meselhy, M.R.; Nakamura, N.; Hattori, M. Biotransformation of (-)-epicatechin-3-O-gallate by human intestinal bacteria. Chem. Pharm. Bull. 1997, 45, 888-893. [CrossRef] [PubMed]

83. Sang, S.; Lambert, J.D.; Ho, C.T.; Yang, C.S. The chemistry and biotransformation of tea constituents. Pharmacol. Res. 2011, 64, 87-99. [CrossRef] [PubMed]

84. Takagaki, A.; Nanjo, F. Catabolism of (+)-catechin and (-)-epicatechin by rat intestinal microbiota. J. Agric. Food Chem. 2013, 61, 4927-4935. [CrossRef] [PubMed]

85. Wang, L.Q.; Meselhy, M.R.; Li, Y.; Nakamura, N.; Min, B.S.; Qin, G.W.; Hattori, M. The heterocyclic ring fission and dehydroxylation of catechins and related compounds by Eubacterium sp. strain SDG-2, a human intestinal bacterium. Chem. Pharma. Bull. 2001, 49, 1640-1643. [CrossRef]

86. Kutschera, M.; Engst, W.; Blaut, M.; Braune, A. Isolation of catechin-converting human intestinal bacteria. J. Appl. Microbiol. 2011, 111, 165-175. [CrossRef] [PubMed]

87. Roowi, S.; Stalmach, A.; Mullen, W.; Lean, M.E.; Edwards, C.A.; Crozier, A. Green tea flavan-3-ols: Colonic degradation and urinary excretion of catabolites by humans. J. Agric. Food. Chem. 2010, 58, 1296-1304. [CrossRef] [PubMed]

88. Schantz, M.; Erk, T.; Richling, E. Metabolism of green tea catechins by the human small intestine. Biotechnol. J. 2010, 5, 1050-1059. [CrossRef] [PubMed]

89. Van't Slot, G.; Humpf, H.U. Degradation and metabolism of catechin, epigallocatechin-3-gallate (EGCG), and related compounds by the intestinal microbiota in the pig cecum model. J. Agric. Food. Chem. 2009, 57, 8041-8048. [CrossRef] [PubMed]

90. Meng, X.; Sang, S.; Zhu, N.; Lu, H.; Sheng, S.; Lee, M.J.; Ho, C.T.; Yang, C.S. Identification and characterization of methylated and ring-fission metabolites of tea catechins formed in humans, mice, and rats. Chem. Res. Toxicol. 2002, 15, 1042-1050. [CrossRef] [PubMed]

91. Takagaki, A.; Nanjo, F. Metabolism of (-)-epigallocatechin gallate by rat intestinal flora. J. Agric. Food Chem. 2010, 58, 1313-1321. [CrossRef] [PubMed]

92. Kohri, T.; Matsumoto, N.; Yamakawa, M.; Suzuki, M.; Nanjo, F.; Hara, Y.; Oku, N. Metabolic fate of (-)-[4-(3)H]epigallocatechin gallate in rats after oral administration. J. Agric. Food. Chem. 2001, 49, 4102-4112. [CrossRef]

93. Kohri, T.; Nanjo, F.; Suzuki, M.; Seto, R.; Matsumoto, N.; Yamakawa, M.; Hojo, H.; Hara, Y.; Desai, D.; Amin, S.; et al. Synthesis of (-)-[4-3H]epigallocatechin gallate and its metabolic fate in rats after intravenous administration. J. Agric. Food. Chem. 2001, 49, 1042-1048. [CrossRef] [PubMed]

94. Fleschhut, J.; Kratzer, F.; Rechkemmer, G.; Kulling, S.E. Stability and biotransformation of various dietary anthocyanins in vitro. Eur. J. Nutr. 2006, 45, 7-18. [CrossRef] [PubMed]

95. Keppler, K.; Humpf, H.U. Metabolism of anthocyanins and their phenolic degradation products by the intestinal microflora. Bioorg. Med. Chem. 2005, 13, 5195-5205. [CrossRef] [PubMed] 
96. Wang, H.; Nair, M.G.; Strasburg, G.M.; Chang, Y.C.; Booren, A.M.; Gray, J.I.; DeWitt, D.L. Antioxidant and antiinflammatory activities of anthocyanins and their aglycon, cyanidin, from tart cherries. J. Nat. Prod. 1999, 62, 294-296. [CrossRef] [PubMed]

97. Hou, D.X. Potential mechanisms of cancer chemoprevention by anthocyanins. Curr. Mol. Med. 2003, 3, 149-159. [CrossRef] [PubMed]

98. Katsube, N.; Iwashita, K.; Tsushida, T.; Yamaki, K.; Kobori, M. Induction of apoptosis in cancer cells by Bilberry (Vaccinium. myrtillus) and the anthocyanins. J. Agric. Food Chem. 2003, 51, 68-75. [CrossRef] [PubMed]

99. Xiao, J.B.; Högger, P. Advance in pharmacokinetics of bioactive polyphenols. Curr. Drug Metab. 2014, 15, 1-2. [CrossRef] [PubMed]

100. Matsumoto, H.; Inaba, H.; Kishi, M.; Tominaga, S.; Hirayama, M.; Tsuda, T. Orally administered delphinidin 3-rutinoside and cyanidin 3-rutinoside are directly absorbed in rats and humans and appear in the blood as the intact forms. J. Agric. Food Chem. 2001, 49, 1546-1551. [CrossRef] [PubMed]

101. Vitaglione, P.; Donnarumma, G.; Napolitano, A.; Galvano, F.; Gallo, A.; Scalfi, L.; Fogliano, V. Protocatechuic acid is the major human metabolite of cyanidin-glucosides. J. Nutr. 2007, 137, 2043-2048. [PubMed]

102. Kahle, K.; Kraus, M.; Scheppach, W.; Ackermann, M.; Ridder, F.; Richling, E. Studies on apple and blueberry fruit constituents: Do the polyphenols reach the colon after ingestion? Mol. Nutr. Food Res. 2006, 50, 418-423. [CrossRef] [PubMed]

103. Aura, A.M.; Martin-Lopez, P.; O’Leary, K.A.; Williamson, G.; Oksman-Caldentey, K.M.; Poutanen, K.; Santos-Buelga, C. In vitro metabolism of anthocyanins by human gut microflora. Eur. J. Nutr. 2005, 44, 133-142. [CrossRef] [PubMed]

104. El Mohsen, M.A.; Marks, J.; Kuhnle, G.; Moore, K.; Debnam, E.; Srai, S.K.; Rice-Evans, C.; Spencer, J.P. Absorption, tissue distribution and excretion of pelargonidin and its metabolites following oral administration to rats. Br. J. Nutr. 2006, 95, 51-58. [CrossRef] [PubMed]

105. Hassimotto, N.M.A.; Genovese, M.I.; Lajolo, F.M. Absorption and metabolism of cyanidin-3-glucoside and cyanidin-3-rutinoside extracted from wild mulberry (Morus nigra L.) in rats. Nutr. Res. 2008, 28, 198-207. [CrossRef] [PubMed]

106. Hanske, L.; Engst, W.; Loh, G.; Sczesny, S.; Blaut, M.; Braune, A. Contribution of gut bacteria to the metabolism of cyanidin 3-glucoside in human microbiota-associated rats. Br. J. Nutr. 2013, 109, 1433-1441. [CrossRef] [PubMed]

107. Wu, X.; Pittman Lii, H.E.; Hager, T.; Hager, A.; Howard, L.; Prior, R.L. Phenolic acids in black raspberry and in the gastrointestinal tract of pigs following ingestion of black raspberry. Mol. Nutr. Food Res. 2009, 53, 76-84. [CrossRef] [PubMed]

108. Tsuda, T.; Horio, F.; Osawa, T. Absorption and metabolism of cyanidin 3-O-beta-D-glucoside in rats. FEBS Lett. 1999, 449, 179-182. [CrossRef]

109. Han, S.J.; Ryu, S.N.; Trinh, H.T.; Joh, E.H.; Jang, S.Y.; Han, M.J.; Kim, D.H. Metabolism of cyanidin-3-O-beta-D-glucoside isolated from black colored rice and its antiscratching behavioral effect in mice. J. Food Sci. 2009, 74, 253-258. [CrossRef] [PubMed]

110. Williamson, G.; Clifford, M.N. Colonic metabolites of berry polyphenols: The missing link to biological activity? Br. J. Nutr. 2010, 104, 48-66. [CrossRef] [PubMed]

111. Andreasen, M.F.; Kroon, P.A.; Williamson, G.; Garcia-Conesa, M.-T. Intestinal release and uptake of phenolic antioxidant diferulic acids. Free Radic. Biol. Med. 2001, 31, 304-314. [CrossRef]

112. Rondini, L.; Peyrat-Maillard, M.-N.; Marsset-Baglieri, A.; Fromentin, G.; Durand, P.; Tome, P.; Prost, M.; Berset, C. Bound ferulic acid from bran is more bioavailable than the free compound in rat. J. Agric. Food Chem. 2004, 52, 4338-4343. [CrossRef] [PubMed]

113. Andreasen, M.F.; Kroon, P.A.; Williamson, G.; Garcia-Conesa, M.T. Esterase activity able to hydrolyze dietary antioxidant hydroxycinnamates is distributed along the intestine of mammals. J. Agric. Food Chem. 2001, 49, 5679-5684. [CrossRef] [PubMed]

114. Gonthier, M.P.; Remesy, C.; Scalbert, A.; Cheynier, V.; Souquet, J.M.; Poutanen, K.; Aura, A.M. Microbial metabolism of caffeic acid and its esters chlorogenic and caftaric acids by human faecal microbiota in vitro. Biomed. Pharmacotherapy 2006, 60, 536-540. [CrossRef] [PubMed]

115. Peppercorn, M.A.; Goldman, P. Caffeic acid metabolism by bacteria of the human gastrointestinal tract. J. Bacteriol. 1971, 108, 996-1000. [PubMed] 
116. Andreasen, M.F.; Christensen, L.P.; Meyer, A.S.; Hansen, A. Content of phenolic acids and ferulic acid dehydrodimers in 17 Rye (Secale cereale L.) varieties. J. Agric. Food Chem. 2000, 48, 2837-2842. [CrossRef] [PubMed]

117. Braune, A.; Bunzel, M.; Yonekura, R.; Blaut, M. Conversion of dehydrodiferulic acids by human intestinal microbiota. J. Agric. Food Chem. 2009, 57, 3356-3362. [CrossRef] [PubMed]

118. Xie, L.Y.; Bolling, B.W. Characterisation of stilbenes in California almonds (Prunus dulcis) by UHPLC-MS. Food Chem. 2015, 148, 300-306. [CrossRef] [PubMed]

119. Mulat, D.G.; Latva-Maenpaa, H.; Koskela, H.; Saranpaa, P.; Wahala, K. Rapid chemical characterisation of stilbenes in the root bark of Norway spruce by off-line HPLC/DAD-NMR. Phytochem. Anal. 2014, 25, 529-536. [CrossRef] [PubMed]

120. Folmer, F.; Basavaraju, U.; Jaspars, M.; Hold, G.; El-Omar, E.; Dicato, M.; Diederich, M. Anticancer effects of bioactive berry compounds. Phytochem. Rev. 2014, 13, 295-322. [CrossRef]

121. Fu, Y.J.; Kadioglu, O.; Wiench, B.; Wei, Z.F.; Gao, C.; Luo, M.; Gu, C.B.; Zu, Y.G.; Efferth, T. Cell cycle arrest and induction of apoptosis by cajanin stilbene acid from Cajanus cajun in breast cancer cells. Phytomedicine 2015, 22, 462-468. [CrossRef] [PubMed]

122. Liu, P.; Wang, Y.R.; Gao, J.Y.; Lu, Z.Y.; Yin, W.P.; Deng, R.X. Resveratrol trimers from seed cake of Paeonia rockii. Molecules 2014, 19, 19549-19556. [CrossRef] [PubMed]

123. Bode, L.M.; Bunzel, D.; Huch, M.; Cho, G.S.; Ruhland, D.; Bunzel, M.; Bub, A.; Franz, C.M.A.P.; Kulling, S.E. In vivo and in vitro metabolism of trans-resveratrol by human gut microbiota. Am. J. Clin. Nutr. 2013, 97, 295-309. [CrossRef] [PubMed]

124. Wang, D.G.; Zhang, Z.W.; Ju, J.F.; Wang, X.Y.; Qiu, W.J. Investigation of piceid metabolites in rat by liquid chromatography tandem mass spectrometry. J. Chromatogr. B 2011, 879, 69-74. [CrossRef] [PubMed]

125. Cassidy, A.; Hanley, B.; Lamuela-Raventos, R.M. Isoflavones: Lignans and stilbenes; origins, metabolism and potential importance to human health. J. Sci. Food Agric. 2000, 80, 1044-1062. [CrossRef]

126. Touillaud, M.S.; Thiebaut, A.C.M.; Fournier, A.; Niravong, M.; Boutron-Ruault, M.C.; Clavel-Chapelon, F. Dietary lignan intake and postmenopausal breast cancer risk by estrogen and progesterone receptor status. J. Natl. Cancer Inst. 2007, 99, 475-486. [CrossRef] [PubMed]

127. Aura, A.-M.; Oikarinen, S.; Mutanen, M.; Heinonen, S.-M.; Ad-lercreutz, H.C.T.; Virtanen, H.; Poutanen, K.S. Suitability of a batch in vitro fermentation model using human faecal microbiota for prediction of conversion of flaxseed lignans to enterolactone with reference to an in vivo rat model. Eur. J. Nutr. 2006, 45, 45-51. [CrossRef] [PubMed]

128. Possemiers, S.; Bolca, S.; Eeckhaut, E.; Depypere, H.; Verstraete, W. Metabolism of isoflavones, lignans and prenylflavonoids by intestinal bacteria: Producer phenotyping and relation with intestinal community. FEMS Microbiol. Ecol. 2007, 6, 1372-1383. [CrossRef] [PubMed]

129. Rowland, I.; Faughnan, M.; Hoey, L.; Wahala, K.; Williamson, G.; Cassidy, A. Bioavailability of phytoestrogens. Br. J. Nutr. 2003, 89, 45-58.

130. Bowey, E.; Adlercreutz, H.; Rowland, I. Metabolism of isoflavones and lignans by the gut microflora: A study in germ-free and human flora associated rats. Food Chem. Toxicol. 2003, 41, 631-636. [CrossRef]

131. Eeckhaut, E.; Struijs, K.; Possemiers, S.; Vincken, J.P.; Keukeleire, D.D.; Verstraete, W. Metabolism of the lignan macromolecule into enterolignans in the gastrointestinal lumen as determined in the simulator of the human intestinal microbial ecosystem. J. Agric. Food Chem. 2008, 56, 4806-4812. [CrossRef] [PubMed]

132. Wang, L.Q.; Meselhy, M.R.; Li, Y.; Qin, G.W.; Hattori, M. Human intestinal bacteria capable of transforming secoisolariciresinol diglucoside to mammalian lignans, enterodiol and enterolactone. Chem. Pharm. Bull. 2000, 48, 1606-1610. [CrossRef] [PubMed]

133. Blaut, M.; Clavel, T. Metabolic diversity of the intestinal microbiota: Implications for health and disease. J. Nutr. 2007, 137, 751-755.

134. Bohn, T. Bioavailability of non-provitamin a carotenoids. Curr. Nutr. Food Sci. 2008, 4, 240-258. [CrossRef]

135. Bouayed, J.; Hoffmann, L.; Bohn, T. Total phenolics, flavonoids, anthocyanins and antioxidant activity following simulated gastro-intestinal digestion and dialysis of apple varieties: Bioaccessibility and potential uptake. Food Chem. 2011, 128, 14-21. [CrossRef] [PubMed]

136. Kemperman, R.A.; Bolca, S.; Roger, L.C.; Vaughan, E.E. Novel approaches for analysing gut microbes and dietary polyphenols: Challenges and opportunities. Microbiology 2010, 156, 3224-3231. [CrossRef] [PubMed] 
137. Williamson, G.; Manach, C. Bioavailability and bioefficacy of polyphenols in humans. II. Review of 93 intervention studies. Am. J. Clin. Nutr. 2005, 81, 243-255.

138. Hollman, P.C.; Katan, M.B. Absorption, metabolism and health effects of dietary flavonoids in man. Biomed. Pharmacother. 1997, 51, 305-310. [CrossRef]

139. Manach, C.; Scalbert, A.; Morand, C.; Remesy, C.; Jimenez, L. Polyphenols: Food sources and bioavailability. Am. J. Clin. Nutr. 2004, 79, 727-747. [PubMed]

140. Lampe, J.W. Interindividual differences in response to plant-based diets: Implications for cancer risk. Am. J. Clin. Nutr. 2009, 89, 1553-1557. [CrossRef] [PubMed]

141. Padayachee, A.; Netzel, G.; Netzel, M.; Day, L.; Zabaras, D.; Mikkelsen, D.; Gidley, M.J. Binding of polyphenols to plant cell wall analogues-Part 2: Phenolic acids. Food Chem. 2012, 135, 2287-2292. [CrossRef] [PubMed]

142. Gil-Izquierdo, A.; Gil, M.I.; Ferreres, F.; Tomas-Barberan, F.A. In vitro availability of flavonoids and other phenolics in orange juice. J. Agric. Food Chem. 2001, 49, 1035-1041. [CrossRef] [PubMed]

143. Mandalaria, G.; Tomaino, A.; Rich, G.T.; Lo Curto, R.; Arcoraci, T.; Martorana, M.; Bisignano, C.; Saija, A.; Parker, M.L.; Waldron, K.W.; et al. Polyphenol and nutrient release from skin of almonds during simulated human digestion. Food Chem. 2010, 122, 1083-1088. [CrossRef]

144. Ozdal, T.; Capanoglu, E.; Altay, F. A review on protein-phenolic interactions and associated changes. Food Res. Int. 2013, 51, 954-970. [CrossRef]

145. Saura-Calixto, F. Dietary fiber as a carrier of dietary antioxidants: An essential physiological function. J. Agric. Food Chem. 2011, 59, 43-49. [CrossRef] [PubMed]

146. Ortega, N.; Reguant, J.; Romero, M.P.; Macia, A.; Motilva, M.J. Effect of fat content on the digestibility and bioaccessibility of cocoa polyphenol by an in vitro digestion model. J. Agric. Food Chem. 2009, 57, 5743-5749. [CrossRef] [PubMed]

147. Tremaroli, V.; Bäckhed, F. Functional interactions between the gut microbiota and host metabolism. Nature 2012, 489, 242-249. [CrossRef] [PubMed]

148. Rothwell, J.A.; Urpi-Sarda, M.; Boto-Ordonez, M.; Knox, C.; Llorach, R.; Eisner, R.; Cruz, J.; Neveu, V.; Wishart, D.; Manach, C.; et al. Phenol-Explorer 2.0: A major update of the Phenol-Explorer database integrating data on polyphenol metabolism and pharmacokinetics in humans and experimental animals. Database 2012, 2012. [CrossRef] [PubMed]

149. Xu, J.; Bjursell, M.K.; Himrod, J.; Deng, S.; Carmichael, L.K.; Chiang, H.C.; Hooper, L.V.; Gordon, J.I. A genomic view of the human-Bacteroides thetaiotaomicron symbiosis. Science 2003, 299, 2074-2076. [CrossRef] [PubMed]

150. Martens, E.C.; Lowe, E.C.; Chiang, H.; Pudlo, N.A.; Wu, M.; McNulty, N.P.; Abbott, D.W.; Henrissat, B.; Gilbert, H.J.; Bolam, D.N.; et al. Recognition and degradation of plant cell wall polysaccharides by two human gut symbionts. PLoS Biol. 2011, 9, 2492. [CrossRef] [PubMed]

151. Donohoe, D.R.; Garge, N.; Zhang, X.; Sun, W.; O'Connell, T.M.; Bunger, M.K.; Bultman, S.J. The microbiome and butyrate regulate energy metabolism and autophagy in the mammalian colon. Cell Metab. 2011, 13, 517-526. [CrossRef] [PubMed]

152. Bäckhed, F.; Manchester, J.K.; Semenkovich, C.F.; Gordon, J.I. Mechanisms underlying the resistance to diet-induced obesity in germ-free mice. Proc. Natl. Acad. Sci. USA 2007, 104, 979-984. [CrossRef] [PubMed]

153. Esposito, D.; Damsud, T.; Wilson, M.; Grace, M.H.; Strauch, R.; Li, X.; Lila, M.A.; Komarnytsky, S. Black currant anthocyanins attenuate weight gain and improve glucose metabolism in diet-induced obese mice with intact, but not disrupted, gut microbiome. J. Agric. Food Chem. 2015, 63, 6172-6180. [CrossRef] [PubMed]

154. Ludwig, I.A.; Mena, P.; Calani, L.; Borges, G.; Pereira-Caro, G.; Bresciani, L.; del Rio, D.; Lean, M.E.J.; Crozier, A. New insights into the bioavailability of red raspberry anthocyanins and ellagitannins. Free Radic. Biol. Med. 2015, 89, 758-769. [CrossRef] [PubMed]

155. Cerdá, B.; Tomás-Barbéran, F.A.; Espín, J.C. Metabolism of antioxidant and chemopreventive ellagitannins from strawberries, raspberries, walnuts, and oak-aged wine in humans: Identification of biomarkers and individual variability. J. Agric. Food Chem. 2005, 53, 227-235. [CrossRef] [PubMed]

156. Seeram, N.P.; Henning, S.M.; Zhang, Y.; Suchard, M.; Li, Z.; Heber, D. Pomegranate juice ellagitannin metabolites are present in human plasma and some persist in urine for up to $48 \mathrm{~h}$. J. Nutr. 2006, 136, 2481-2485. [PubMed] 
157. González-Barrio, R.; Borges, G.; Mullen, W.; Crozier, A. Bioavailability of anthocyanins and ellagitannins following consumption of raspberries by healthy humans and subjects with an ileostomy. J. Agric. Food. Chem. 2010, 58, 3933-3939. [CrossRef] [PubMed]

158. González-Barrio, R.; Edwards, C.A.; Crozier, A. Colonic catabolism of ellagitannins, ellagic acid, and raspberry anthocyanins: In vivo and in vitro studies. Drug Metab. Dispos. 2011, 39, 1680-1688. [CrossRef] [PubMed]

159. Dudonné, S.; Varin, T.V.; Anhê, F.F.; Dubé, P.; Roy, D.; Pilon, G.; Marette, A.; Levy, E.; Jacquot, C.; Urdaci, M.; et al. Modulatory effects of a cranberry extract co-supplementation with Bacillus subtilis CU1 probiotic on phenolic compounds bioavailability and gut microbiota composition in high-fat diet-fed mice. PharmaNutrition 2015, 3, 89-100. [CrossRef]

160. Halliwell, B.; Rafter, J.; Jenner, A. Health promotion by flavonoids, tocopherols, tocotrienols, and other phenols: Direct or indirect effects? Antioxidant or not? Am. J. Clin. Nutr. 2005, 81, 268-276.

161. Choy, Y.Y.; Jaggers, G.K.; Oteiza, P.I.; Waterhouse, A.L. Bioavailability of intact proanthocyanidins in the rat colon after ingestion of grape seed extract. J. Agric. Food Chem. 2013, 61, 121-127. [CrossRef] [PubMed]

162. He, J.; Magnuson, B.A.; Giusti, M.M. Analysis of anthocyanins in rat intestinal contentsimpact of anthocyanin chemical structure on fecal excretion. J. Agric. Food Chem. 2005, 53, 2859-2866. [CrossRef] [PubMed]

163. Gibson, G.R. Prebiotics as gut microflora management tools. J. Clin. Gastroenterol. 2008, 42, 75-79. [CrossRef] [PubMed]

164. Burcelin, R.; Garidou, L.; Pomie, C. Immuno-microbiota cross and talk: The new paradigm of metabolic diseases. Semin. Immunol. 2012, 24, 67-74. [CrossRef] [PubMed]

165. Rastall, R.A.; Gibson, G.R.; Gill, H.S.; Guarner, F.; Klaenhammer, T.R.; Pot, B.; Reid, G.; Rowland, I.R.; Sanders, M.E. Modulation of the microbial ecology of the human colon by probiotics, prebiotics and synbiotics to enhance human health: An overview of enabling science and potential applications. FEMS Microbiol. Ecol. 2005, 52, 145-152. [CrossRef] [PubMed]

166. Duda-Chodak, A. The inhibitory effect of polyphenols on human gut microbiota. J. Physiol. Pharmacol. 2012, 63, 497-503. [PubMed]

167. Etxeberria, U.; Arias, N.; Boqué, N.; Macarulla, M.T.; Portillo, M.P.; Martínez, J.A.; Milagro, F.I. Reshaping faecal gut microbiota composition by the intake of trans-resveratrol and quercetin in high-fat sucrose diet-fed rats. J. Nutr. Biochem. 2015, 26, 651-660. [CrossRef] [PubMed]

168. Kawabata, K.; Sugiyama, Y.; Sakano, T.; Ohigashi, H. Flavonols enhanced production of anti-inflammatory substance(s) by Bifidobacterium adolescentis: Prebiotic actions of galangin, quercetin, and fisetin. Biofactors 2013, 39, 422-429. [CrossRef] [PubMed]

169. Parkar, S.G.; Stevenson, D.E.; Skinner, M.A. The potential influence of fruit polyphenols on colonic microflora and human gut health. Int. J. Food Microbiol. 2008, 124, 295-298. [CrossRef] [PubMed]

170. Clavel, T.; Fallani, M.; Lepage, P.; Levenez, F.; Mathey, J.; Rochet, V.; Serezat, M.; Sutren, M.; Henderson, G.; Bennetau-Pelissero, C.; et al. Isoflavones and functional foods alter the dominant intestinal microbiota in postmenopausal women. J. Nutr. 2005, 135, 2786-2792. [PubMed]

171. Tzounis, X.; Vulevic, J.; Kuhnle, G.G.C.; George, T.; Leonczak, J.; Gibson, G.R.; Kwik-Uribe, C.; Spencer, J.P.M. Flavanol monomer-induced changes to the human faecal microflora. Br. J. Nutr. 2008, 99, 782-792. [CrossRef] [PubMed]

172. Cueva, C.; Sánchez-Patán, F.; Monagas, M.; Walton, G.E.; Gibson, G.R.; Martín-Álvarez, P.J.; Bartolome, B.; Moreno-Arribas, M.V. In vitro fermentation of grape seed flavan-3-ol fractions by human faecal microbiota: Changes in microbial groups and phenolic metabolites. FEMS Microbiol. Ecol. 2013, 83, 792-805. [CrossRef] [PubMed]

173. Choy, Y.Y.; Quifer-Rada, P.; Holstege, D.M.; Frese, S.A.; Calvert, C.C.; Mills, D.A.; Lamuela-Raventos, R.M.; Waterhouse, A.L. Phenolic metabolites and substantial microbiome changes in pig feces by ingesting grape seed proanthocyanidins. Food. Funct. 2014, 5, 2298-2308. [CrossRef] [PubMed]

174. Hidalgo, M.; Oruna-Concha, M.J.; Kolida, S.; Walton, G.E.; Kallithraka, S.; Spencer, J.P.; de Pascual-Teresa, S. Metabolism of anthocyanins by human gut microflora and their influence on gut bacterial growth. J. Agric. Food Chem. 2012, 60, 3882-3890. [CrossRef] [PubMed]

175. Bialonska, D.; Kasimsetty, S.G.; Schrader, K.K.; Ferreira, D. The effect of pomegranate (Punica granatum L.) byproducts and ellagitannins on the growth of human gut bacteria. J. Agric. Food Chem. 2009, 57, 8344-8349. [CrossRef] [PubMed] 
176. Bialonska, D.; Ramnani, P.; Kasimsetty, S.G.; Muntha, K.R.; Gibson, G.R.; Ferreira, D. The influence of pomegranate by-product and punicalagins on selected groups of human intestinal microbiota. Int. J. Food Microbiol. 2010, 140, 175-182. [CrossRef] [PubMed]

177. Larrosa, M.; Gonzalez-Sarrıas, A.; Yanez-Gascon, M.J.; Selma, M.V.; Azorın-Ortuno, M.; Toti, S.; Tomas-Barberan, F.A.; Dolara, P.; Espın, J.C. Anti-inflammatory properties of a pome-granate extract and its metabolite urolithin-A in a colitis rat model and the effect of colon inflammation on the phenolic metabolism. J. Nutr. Biochem. 2010, 21, 717-725. [CrossRef] [PubMed]

178. Li, Z.; Henning, S.M.; Lee, R.-P.; Lu, Q.-Y.; Summanen, P.H.; Thames, G.; Corbett, K.; Downes, J.; Tsena, C.-H.; Finegold, S.M.; et al. Pomegranate extract induces metabolite formation and changes stool microbiota in healthy volunteers. Food Funct. 2015, 6, 2487-2495. [CrossRef] [PubMed]

179. Larrosa, M.; Yanez-Gascon, M.J.; Selma, M.V.; Gonzalez-Sarrıs, A.; Toti, S.; Ceron, J.J.; Tomas-Barberan, F.A.; Dolara, P.; Espin, J.C. Effect of a low dose of dietary resveratrol on colon microbiota, inflammation and tissue damage in a DSS-induced colitis rat model. J. Agric. Food Chem. 2009, 57, 2211-2220. [CrossRef] [PubMed]

180. Qiao, Y.; Sun, J.; Xia, S.; Tang, X.; Shi, Y.; Le, G. Effects of resveratrol on gut microbiota and fat storage in a mouse model with high-fat-induced obesity. Food Funct. 2014, 5, 1241-1249. [CrossRef] [PubMed]

181. Niemi, P.; Aura, A.M.; Maukonen, J.; Smeds, A.I.; Mattila, I.; Niemelä, K.; Tamminen, T.; Fauulds, C.B.; Buchert, J.; Poutanen, K. Interactions of a lignin-rich fraction from Brewer's spent grain with gut microbiota in vitro. J. Agric. Food Chem. 2013, 61, 6754-6762. [CrossRef] [PubMed]

(C) 2016 by the authors; licensee MDPI, Basel, Switzerland. This article is an open access article distributed under the terms and conditions of the Creative Commons by Attribution (CC-BY) license (http://creativecommons.org/licenses/by/4.0/). 